Portland State University

PDXScholar

\title{
El impacto social del alcoholismo en Chin Chin el Teporocho $=$ The social impact of alcoholism in Chin Chin el Teporocho
}

Juan Carlos Hernández

Portland State University

Follow this and additional works at: https://pdxscholar.library.pdx.edu/open_access_etds

Part of the Film and Media Studies Commons, and the Spanish and Portuguese Language and Literature Commons

Let us know how access to this document benefits you.

\section{Recommended Citation}

Hernández, Juan Carlos, "El impacto social del alcoholismo en Chin Chin el Teporocho $=$ The social impact of alcoholism in Chin Chin el Teporocho" (1997). Dissertations and Theses. Paper 5390. https://doi.org/10.15760/etd.7263

This Thesis is brought to you for free and open access. It has been accepted for inclusion in Dissertations and Theses by an authorized administrator of PDXScholar. Please contact us if we can make this document more accessible: pdxscholar@pdx.edu. 
The abstract and thesis of Juan Carlos Hernández Cuevas for the Master of Arts in Spanish were presented June 2, 1997, and accepted by the thesis committee and the department.

COMMITTEE APPROVALS:

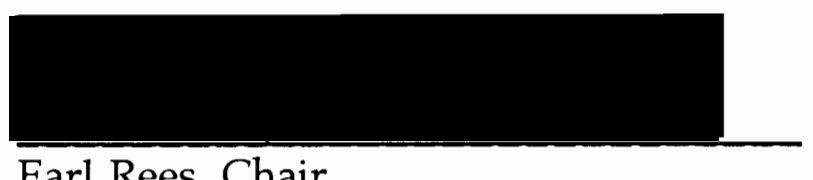

Earl Rees, Chair

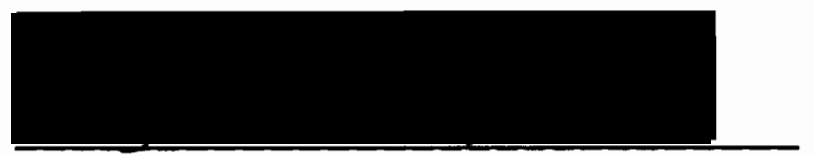

George T. Cabello

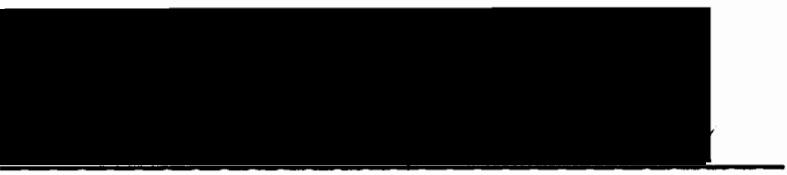

Friedrich E. Schuler

Representative of the Office of Graduate Studies

DEPARTMENT APPROVAL:

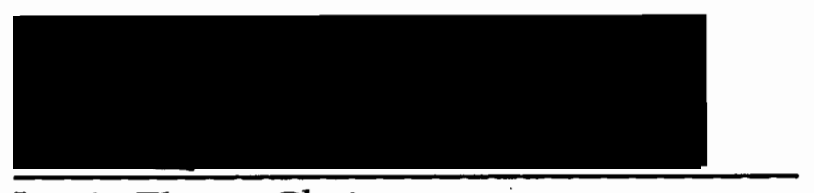

Louis Elteto, Chair

Department of Foreign Languages

\section{ACCEPTED FOR PORTLAND STATE UNIVERSITY BY THE LIBRARY}

by on

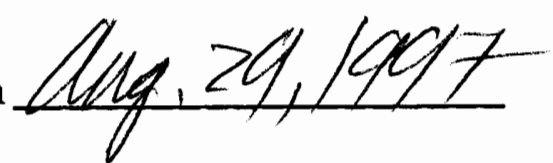




\section{ABSTRACT}

An abstract of the thesis of Juan Carlos Hernández Cuevas for the Master in Spanish presented June 2, 1997.

Title: El impacto social del alcoholismo en Chin Chin el teporocho.

(The social impact of alcoholism in Chin Chin el teporocho.)

La idea central de esta investigación es analizar el impacto social del alcoholismo en la novela urbana Chin Chin el teporocho de Armando Ramírez, cuya narración se ubica en el barrio de Tepito, en México, Distrito Federal.

El autor, a través de un panorama histórico y ágil, informa al lector del consumo de bebidas embriagantes en la ciudad de México y su respectivo impacto en la sociedad tepiteña, así como la aparición social y psicológica del personaje identificado por Ramírez como el Teporocho.

En este estudio, Hernández nos confronta con la violencia verbal y física que existe en Chin Chin a consecuencia de la ingestión excesiva del alcohol, lo cual se refleja en el comportamiento y lenguaje del protagonista y otros personajes de la novela. Además, indica que en el texto se percibe una amplia problemática social, estrechamente relacionada con la constante presencia del licor en el ambiente de Tepito.

Rogelio, sus amigos y otros personajes son el reflejo de dos clases sociales, integradas por gente joven y madura, conscientes hasta cierto punto de su realidad social, frente a la cual, el licor es un medio de escape y causa principal de la autodestrucción moral y física de la mayoría de 
ellos. El choque e influencia social del alcoholismo en el barrio, los conduce a la perdición, creándose así una subclase de individuos económica y socialmente marginados, a punto de extinción.

En esta novela, el alcohol cobra vida, es un personaje casi dios de los despojados; los influye y controla de tal manera, que devora todo y a todos a su paso, dejando únicamente devastación social. 
EL IMPACTO SOCIAL DEL ALCOHOLISMO

EN CHIN CHIN EL TEPOROCHO

\title{
(THE SOCIAL IMPACT OF ALCOHOLISM \\ IN CHIN CHIN EL TEPOROCHO)
}

\author{
by \\ JUAN CARLOS HERNÁNDEZ CUEVAS
}

A thesis submitted in partial fulfillment of the requirements for the degree of

MASTER OF ARTS

in

SPANISH

Portland State University

1997 


\section{Indice}

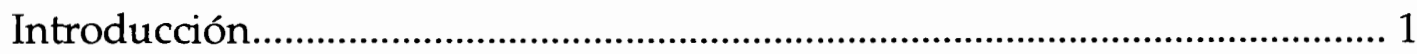

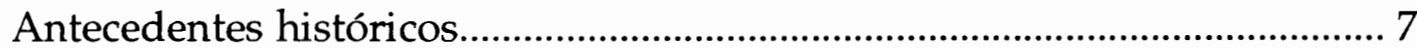

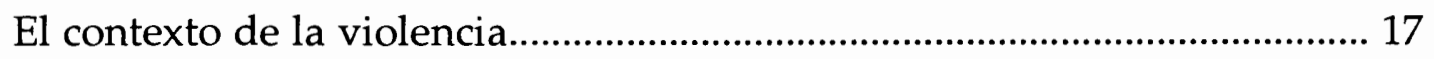

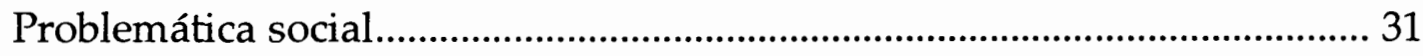

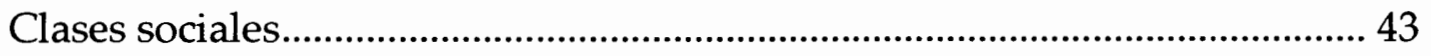

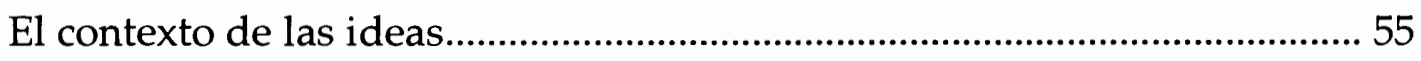

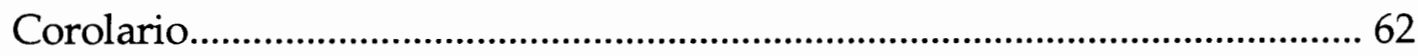

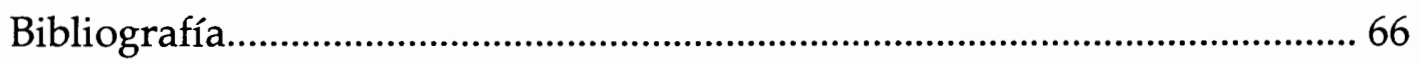




\section{El impacto social del alcoholismo en Chin Chin el teporocho}

\section{Introducción}

El crítico literario estadounidense John S. Brushwood, considera a Chin Chin el teporocho como una de las más importantes novelas mexicanas de las últimas décadas del siglo XX. Indica al mismo tiempo que su autor "es un excelente narrador que logra describir los hábitos y problemas en la vida de un barrio proletario de la capital" (La novela mexicana 66). El dramaturgo mexicano Emilio Carballido ha comentado que la narración de Ramírez es exitosísima, reeditada muchas veces y de la cual existe una versión cinematográfica espléndida (El Nacional, 13 marzo 1993: 20). Sin embargo, la novela desde su publicación en 1972, no ha tenido una buena acogida de parte de la crítica literaria nacional e internacional, y su difusión se debe al reconocimiento del público lector (Foster 438-39).

Armando Ramírez Rodríguez (1950), es uno de los escritores con mayor auge y popularidad en el Distrito Federal. Además de participar en la conducción de un programa televisivo, se dedica a escribir cuentos, guiones, a ser reportero y al montaje teatral de sus novelas. Su amplio entendimiento de las costumbres y modo de vida de los barrios populares que rodean el centro de la ciudad de México, le ha otorgado el título de cronista de Tepito (Gaceta UNAM, 29 julio 1993: n. pág.). 
Chilango ${ }^{1}$ de nacimiento y tepiteño de corazón, Ramírez se ha inspirado en el barrio de Tepito, para escribir la mayor parte de su prolífica obra: El regreso de Chin Chin el teporocho en: La venganza de los jinetes justicieros, $\mathrm{Pu}$ o Violación en Polanco, Noche de califas, Tepito, Quinceañera, Me llaman la chata Aguayo, y finalmente Crónica de los chorrocientos mil días del barrio de Tepito, o, en donde se ve como obrero, ratero, prostituta, boxeador y comerciante, juegan a las pipis $y$ gañas, o sea, en donde todos juntos comeremos chi-cha-rrón.

Chin Chin el teporocho, narra la dramática existencia de un joven huérfano llamado Rogelio, y conocido por el mote de Chin Chin, en la década de los sesenta. Vive en una humilde vecindad de Tepito, con sus tíos y dos primos, Víctor y Sonia. Asimismo, mantiene una relación amorosa sexual con Michele, una atractiva muchacha criolla de la clase media, hija de un refugiado español que se dedica con éxito al negocio de ultramarinos en Tepito. Rogelio la ve por primera vez en una fiesta del barrio.

En una borrachera, su primo hermano Víctor es asesinado, y un poco después Sonia muere a consecuencia de su participación política en el movimiento estudiantil de 1968. Más tarde, Michele y Chin Chin al ser descubiertos in fraganti, son obligados a contraer nupcias. A pesar de su gran amor, jamás llegan a ser felices debido a la dependencia económica en el padre de ella. A la vez, Rogelio descubre que su suegro mantiene

${ }^{1}$ De acuerdo al Diccionario de Mejicanismos de Santamaría, chilango proviene del maya xilaan; pelo revuelto o encrespado. También es el apodo popular que se da al habitante del Distrito Federal, en especial al pelado (971). 
relaciones homosexuales con su ex amigo Rubén, de quien existe sospecha de haber matado a Víctor. Ante la circunstancia del momento, los dos jóvenes se enfrentan y pelean a muerte; sobrevive sólo Rogelio, y logra vengar a su primo. Este hecho, destruye su matrimonio, haciendo que Michele decida abandonarlo para huir con su padre. En consecuencia, Chin Chin se convierte en teporocho: Un "dipsómano lumpen" (Contraportada de Chin Chin).

Chin Chin tiene lugar en Tepito, barrio de origen prehispánico y originalmente poblado por macehuales. ${ }^{2}$ Salvador Novo indica que el nombre Tepito significa en náhuatl cosa pequeña o poca cosa (Tepito 14). Ramírez ubica a esta barriada entre dos colonias del Distrito Federal, la Morelos y el Centro. Igualmente es parte de la Delegación Política Cuauhtémoc y de la Venustiano Carranza. Sus ochenta y cuatro manzanas van desde Reforma Norte, por el rumbo de Peralvillo, hasta las calles de la República de Costa Rica, Canal del Norte y Ferrocarril Cintura. Según el autor, en Tepito viven ciento cincuenta mil personas, y sus mercados y pobladores atraen más o menos la atención de un millón ochocientos cincuenta mil visitantes cada día. En su perímetro, hay varios mercados históricos e importantes: "la Lagunilla, Zona Tepito, Tepito Fierros, Tepito Muebles, Tepito Ropa." Hoy, "Tepito es cuna de futbolistas, boxeadores, luchadores, vendedores de contrabando y también de seres como los que se pudieran encontrar en otra parte" (Tepito 11-12).

2 Macehuales: Indios plebeyos. Proviene del nahuatlismo macehualli. Vasallo, villano; de macehua, bailar, hacer penitencia, servir. (Cabrera 87) "El indio de condición más humilde, dedicado a los quehaceres más bajos" (Santamaría 673). 
El área de Tepito "ocupa menos de 1.5 kilómetros cuadrados" (Romero 1992, 42) y su medio ambiente ha sido definido por el periodista norteamericano Sam Quiñones, como el corazón del infierno, apartado y con su propio lenguaje y humor; un lugar en donde se desconfía de la gente que no pertenece al barrio (40) (Trad.). ${ }^{3}$ El ensayista Héctor Romero al referirse a la construcción de la ciudad de México, apunta que la barriada quedó fuera de la traza urbana reservada a los conquistadores españoles, volviéndose lugar obligatorio de residencia para indígenas marginados. Desde entonces sus habitantes han desarrollado una fuerte autosuficiencia urbana y conciencia de clase y barrio (35). Alan Riding añade que entre otras características sobresalientes del proletario y rudo Tepito, se debe indicar el predominio de un espíritu sólido de supervivencia, lealtad comunitaria y familiar, y ser cuna de notables talentos artísticos (266). Concluye el antropólogo y sociólogo Roger Bartra que en este lugar han surgido formas de defensa popular de la cultura local, a través de un movimiento artístico, llamado "arte acá" (128) (Trad.). De la misma manera, Ramírez comenta: "Quien es inculto en Tepito es porque quiere" (Tepito 11).

No obstante a que Chin Chin el teporocho fue publicado hace veinticinco años, y que Tepito experimentó grandes transformaciones económicas en los años ochenta con el incremento de la venta de fayuca, ${ }^{4}$

3 Debido al uso de fuentes informativas escritas en inglés, se incluye (Trad.), con el propósito de indicar la traducción de textos del inglés al español.

4 Fayuca: contrabando de equipo electrónico y eléctrico, ropa, zapatos tenis, etc., (Quiñones 44). 
y daños durante los terremotos de 1985, en lo que respecta a lo social pocas cosas han cambiado en el barrio. En la actualidad, a un lado de la enorme influencia social de las drogas aludidas en la novela, tales como el alcohol, la mariguana y las pastillas, existe un alarmante consumo de cocaína por parte de los adolescentes y una ola de delitos al azar (Quiñones 46) relacionada con el consumo de ésta. El investigador Arturo Melgoza Paralizábal expresa que los tepiteños todavía carecen de una adecuada estabilidad laboral, lo cual continúa siendo una antigua y actual promesa gubernamental. Aunque un sector reducido de éstos obtiene ingresos respetables por medio del comercio, la mayoría trabaja sin ningún tipo de protección social, y otros han aprendido a sobrevivir frente al inherente fatalismo y la fuerza destructiva del alcohol, tal y como sucede en Chin Chin el teporocho (Entrevista. Enero 31 de 1997).

En el texto de Ramírez hay muchísimas palabras que tienen que ver con el alcohol, las cuales establecen una relación directa con las existencias de la mayoría de los personajes, cuyos destinos se ven rodeados por la presencia omnímoda de este líquido, provocando así un encontronazo social en sus vidas, desde el principio hasta el final del relato. De acuerdo a la definición de la Organización Mundial de la Salud, gran parte de ellos padecen de alcoholismo:

[U]na enfermedad crónica, un desorden de la conducta caracterizado por la ingestión repetida de bebidas alcohólicas hasta el punto de que excede a lo que está socialmente aceptado y que interfiere con la salud del bebedor, así como 
sus relaciones interpersonales o con su capacidad para el trabajo. (Gaceta UNAM 1 abril 1993: n. pág.)

La idea central de nuestra investigación, es analizar el impacto social del alcoholismo en Chin Chin el teporocho. Por lo tanto, se llevará a cabo un estudio del papel del alcohol y la dipsomanía en la novela, a través del señalamiento de su gestación e influencia histórica, la consecuente violencia verbal y física, además de la extensa problemática social, cultural e ideológica, con el propósito de ubicarlo como un actual fenómeno social de gravedad. El rigor y la severidad académicas que exige un trabajo como éste, obliga a examinar el fenómeno con alguna profundidad médica, antropológica y social, deslindando factores económicos, políticos, ideológicos y culturales.

La crítica literaria M. Isela Chiu-Olivares explica que Armando Ramírez en un "afán por reconstruir el ambiente y las costumbres del medio" de Tepito, "utiliza el vocabulario típico juvenil y expresiones callejeras, hace caso omiso de algunas reglas gramaticales, conserva las formas erradas incluyendo incorrecciones ortográficas e ignora las reglas de puntuación" (98-99). El investigador Steven M. Bell cataloga a este lenguaje como realista y popular (Handbook of Latin American Literature 438). En Chin Chin, se incluye una nota explicativa casi al principio de la novela para aclarar los "vicios de dicción" (González Peña 3): "para el poco respeto que se le tiene al lector, (a): las omisiones, errores y demas defectos que le encuentren a esta "mi obsesion" echelen la culpa al AUTOR" (17). 


\section{Antecedentes Históricos}

La novela urbana Chin Chin el teporocho gira alrededor del licor, asentando en sus páginas una conexión abierta entre la enorme ingestión de bebidas espirituosas y el efecto social producto de éstas. Ya que Tepito es un barrio que ha existido desde tiempos prehispánicos, su situación social es una realidad con siglos de abolengo en la ciudad de México. El papel decisivo del alcohol en la vida de los personajes ramirianos en Chin Chin y en los actuales tepiteños, se puede entender mucho mejor si uno tiene una idea general de su historia, desde su origen en el México antiguo hasta nuestros días. De esta forma se pueden establecer las causas del actual impacto del alcoholismo como fenómeno social, producto del consumo excesivo y prolongado de bebidas embriagantes en la capital mexicana, y específicamente en las vicisitudes de los personajes que integran la narración de Armando Ramírez, cuyo desarrollo ubica el autor en Tepito. En esta novela encontramos un extenso vocabulario que se relaciona abiertamente con el alcohol, la borrachera y la dipsomanía de gran número de los personajes, por lo cual se requiere de este minucioso estudio, con el objetivo de llegar a entender el enorme efecto catastrófico de la beberecua en el relato de Ramírez.

El vino, palabra que en lenguaje popular del Distrito Federal se refiere a las bebidas alcohólicas fuertes en general, es y ha sido parte del medio ambiente social y cultural del país desde la época precolombina. La obra México a Través de los Siglos advierte que "los nahoas hacían vino del mexcal, y lo sacaban también de estas pitahayas, de las tunas ó nochtli, 
de las semillas del mesquite y del maíz; pero la más fuerte se hacía del sauco" (Riva Palacio 1: 127). En La Conquista de México, López de Gómara indica que los mexicas preparaban un "vino de maíz cocido con hierbas y raíces" (453). Al visitar la Nueva España el sabio Alejandro de Humboldt anota en su obra los resultados de sus observaciones y posible experimentación con el mexcal o aguardiente, describiéndolo como "un brandy muy intoxicante" (2: 527). Sin soslayar la histórica presencia y popularidad del pulque en México, fray Bernardino de Sahagún lo categoriza como "un licor producido por la fermentación del jugo del maguey" (4: 347).

Reiterando el precedente y prominencia del pulque, Melgoza nos explica cómo Xóchitl le entregó la "miel prieta" a Tecpancaltzin:

El rey de los toltecas se enamoró de Xóchitl. Y se quedó con ella, más la "miel prieta" con el pretexto de que iba a educarla. Al poco tiempo la doncella y Tecpancaltzin tuvieron un hijo, al que pusieron el nombre Meconetzin, que quiere decir hijo del maguey. ("El pulque" 20)

Francisco Hernández en Antigüedades de la Nueva España, menciona a Ometochtli, el dios del vino: "representado sosteniendo sobre la cabeza un barril, que llenaban de pulque cuando celebraban su fiesta, lo cual acontecía a menudo" (136). Igualmente, su referencia incluye a un segundo dios del vino, Izquitécatl, venerado en su templo con extraordinarias cantidades de este licor (164).

El maguey causa impresiones diversas tanto en Motolinía como en Humboldt, dos cronistas que logran describir la planta y su producto 
embriagador. El primero de éstos, en Relaciones de la Nueva España, relata: "después de que el metl o maguey está hecho y tiene su cepa crecida, córtanle el cogollo con cinco o seis púas que allí las tienen tiernas ..." (121). Humboldt, por medio de cuidadosas anotaciones, señala la importancia del cultivo del maguey de pulque en México, informándonos que a los ocho años de crecimiento, la planta mide metro y medio de altura, y llega a producir grandes cantidades de agua miel, el cual, al ser fermentado se transforma en pulque (2: 521-27).

La relevancia comercial de las bebidas alcohólicas en el México prehispánico, aparece en la Segunda Carta de Relación que el capitán Hernán Cortés envía al emperador de España, Carlos V, quien al leer atentamente dicha correspondencia, redescubre también este mundo. Cortés notifica a su majestad acerca de la existencia de plantas cuyo licor se vende entre los habitantes de México (63).

Algunos años después, consumada ya la conquista de México, el padre Motolinía declara la presencia de un vino utilizado por los indígenas para emborracharse, y entonces actuar como bárbaros (122). En base a los escritos de Motolinía, el historiador Mariano Cuevas agrega lo siguiente: "La historia, según se ve por este testimonio, y pudiera verse por otros muchos, no está de acuerdo con los que aseguran que no existió la embriaguez antes de la Conquista" (1: 132). El susodicho comportamiento de los aborígenes también causa asombro ante la mirada incrédula de otro fraile: "Pocas fiestas hacían sin borracheras a la noche, y otras cosas que de ello suelen suceder" (Historia Eclesiástica Indiana 1: 107). Durante el trancurso del mismo siglo, el padre "Bernardino de 
Sahagún tipificaba las diversas clases de borrachos. Aclaraba que el vino se llama centzontotochtin, que quiere decir 400 conejos, porque tiene muchas y diversas formas de borrachería" ("Fray Bernardino" 30).

Diversas fuentes históricas mencionan la presencia del alcohol en el mundo precortesiano, citando que sus habitantes gustaban de la borrachera (Riva Palacio 1: 127). En el México antiguo encontramos un control muy estricto y restringido en cuanto a su consumo. Sahagún apunta, "solamente los que eran ya viejos bebían el vino muy secretamente y bebían pero no se emborrachaban" (1: 308). El cronista Francisco Javier Clavijero señala la imposición de una rigurosa legislación en el mundo náhuatl, dirigida a suspender el gusto por la bebida (1: 138). Vicente Riva Palacio reafirma lo anterior explicando que la intoxicación desmesurada producto de la borrachez, constituía serio delito y vicio que propende al robo (1: 660). Nos informa Sahagún que entre los jóvenes del Telpochcali, las penalidades por el consumo o posesión del licor acarreaba consecuencias muy serias:

Y si aparecía un mancebo borracho públicamente o si lo topaban con el vino, o lo veían caído en la calle o iba cantando, o estaba acompañado con los otros borrachos, este tal, si era macegual castigábanle dándole palos hasta matarle, o le daban garrote delante de todos los mancebos juntados, porque tomasen ejemplo y medio de no emborracharse.

Riva Palacio apunta que la borrachera y su respectivo escándalo, eran punibles: 
[Y] así a los borrachos y á los que comenzaban á cantar y á dar voces por el valor de la bebida los trasquilaban afrentosamente en la plaza, y si tenían la embriaguez por vicio, les derribaban sus casas porque eran indignos de contarse entre los vecinos; los privaban de los oficios públicos que tenían y quedaban inhábiles para tenerlos en adelante. (1: 661)

La severidad de la ley castigaba con pena de muerte al "mancebo del Calmecac, el sacerdote y la mujer moza que se embriagaban" (Riva Palacio 1: 661).

Fray Bernardino de Sahagún, en sus detallados estudios de la borrachería durante la primera centuria de la Colonia, describe a cierto tipo de borracho: "y no puede dejar de beber vino, ni lo puede olvidar un solo día ni puede estar sin emborracharse, y anda cayéndose lleno de polvo y bermejo, y todo espeluzado y descabellado y muy sucio ..." ("Las siete caídas" 21). Este ejemplo denota la presencia de los estragos del alcoholismo, y también advierte la aparición de los ancestros coloniales de los teporochos que aparecen en la novela Chin Chin el teporocho.

Ciento treinta y un años después de la caída de Tenochtitlán, ya en plena época colonial, "se prohibieron las bebidas embriagantes el 9 de julio de 1652, reglamentándose la venta del pulque y vino tinto, así como bebidas de moderación" ("El pulque" 21). El libro The Limits of Ratial Domination: Plebeian Society in Mexico City, expone que en 1681, durante las noches de mercado, el actual Zócalo de la capital, se convierte en punto de reunión de toda clase de individuos, tales como "esclavos 
fugitivos, mulatos, mestizos, indios y algunos españoles, cuyas actividades se concretaban en beber alcohol y fornicar con las marchantas" (37) (Trad.). Melgoza indica que en el transcurso del mismo siglo se restringe el número de pulquerías en la ciudad de México a 36; prohibiéndose totalmente la introducción del pulque a la capital para finales del siglo XVII. Una situación que dura sólo cinco años. En 1747 el virrey Revillagigedo ordena que las pulquerías cierren a las 9 de la noche ("El pulque" 21).

Las observaciones en torno a la borrachez de los mexicanos, continúan causando controversia en la nueva sociedad. En consecuencia, la pluma e ingenio de Francisco Javier Clavijero aluden lo siguiente, en relación al "carácter de los mexicanos:" "Son y han sido muy sobrios en la comida; pero es vehemente su inclinación a los licores espirituosos . . . hoy la abundancia de semejantes licores y la impunidad de la embriaguez los ha puesto en tal estado, que la mitad de la nación no acaba el día en su juicio ..." (1: 138).

En el siglo XIX, la influencia del alcohol llegó a tener tanto arraigo social y cultural en la población de la ciudad de México, que ni aún la primera novela mexicana se encuentra exenta de la presencia del licor, de su respectiva crítica social y consumidores. Joaquín Fernández de Lizardi narra en las páginas de la novela El Periquillo Sarniento, lo que será un antecedente y punto de partida para la narrativa de Armando Ramírez en Chin Chin el teporocho, ya que el texto "neo-costumbrista" (Foster 438) de Ramírez presenta también "ideas políticas, filosóficas y religiosas" y "la necesidad intelectual de decir la verdad" a través de "el costumbrismo de 
ciertas descripciones y el lenguaje de típica raigambre popular mexicana" (Alegría 16).

[P]orque hay dos clases de tunantismo; una soez y arrastrada como la de los enfrazados y borrachos que juegan a la rayuela o la taba en una esquina, que se trompean en las calles, que llevan a otras "leperuzcas" descalzas y hechas pedazos, y se emborrachan públicamente en las pulquerías y tabernas, y éstos se llaman pillos y "léperos" ordinarios. (Fernández de Lizardi 72)

A principios de la misma centuria, las calles de la capital albergaban de veinte a treinta mil indigentes apodados Saragates o Guachinangos, quienes se dedicaban a trabajar por uno o dos días a la semana, con el objetivo de comprar pulque (Humboldt 1: 235). Además, la presencia de éstos, conocidos también como léperos, provoca gran escándalo en la sociedad mexicana debido a las enormes cantidades que consumían de pulque y a su aspecto atroz y lastimero (Cumberland 173). Durante el mismo período histórico, Fernando Benítez indica un marcado alcoholismo entre la raza indígena (1:20). El aspecto y comportamiento social en general de los teporochos que aparecen en Chin Chin, se asemeja muchísimo a la imagen y conducta de los aludidos léperos.

En 1822, Alejandro de Humboldt en su Ensayo Político del Reino de la Nueva España, apunta un incremento del consumo de vinos finos en México a partir del año 1791; accesibles únicamente para las clases pudientes; mientras el jugo fermentado del agave o pulque continuaba siendo la bebida preferida de indios, mestizos, mulatos y de un gran 
número de criollos; consumiéndose éste en desmesuradas cantidades anualmente (2: 93-95). El testimonio de una viajera inglesa, corrobora lo dicho con anterioridad por Humboldt, informándonos que en la ciudad de México, la ingestión desmedida del pulque entre la población ha enriquecido enormemente a varias familias respetables de la capital (Calderón de la Barca 94). Por esa época, aumentan las importaciones de brandy, vino tinto y blanco, y licores finos (Humboldt 4: 31-34).

El día 18 de julio de 1868, se publica en La Orquesta una apología al pulque:

Que no es posible por más tiempo soportar la persecución de que yo y mi familia somos víctimas desde hace años. Relegados en los barrios de la ciudad los expendios de pulque, el centro ha quedado enteramente a merced de nuestros naturales enemigos el Cognac, el Brandy, el Ajenjo y otros. ("El pulque" 24-25)

En Historia Moderna de México, se subraya un aumento desproporcionado del número de cantinas en la capital del país entre 1864 y 1885; de 51 establecimientos se llega a 817 . También se generaliza la adicción y gusto por el vino blanco y rojo, el coñac y moscatel de Parras. Anteriormente, los capitalinos sólo bebían pulque y mezcal (Cosío 4:73).

En 1896, se acusa al pulque de ser la causa del incremento de delitos violentos en la capital. Durante esta época se considera al abuso de bebidas alcohólicas como un problema social muy serio en la ciudad, en donde ya se encuentran establecidas " 16 destilerías de alcohol y cerveza, 458 expendios de vinos, y 1761 de pulque" (Piccato 208) (Trad.). En 1906, se 
prohíbe la venta de café y hojas de naranjo con alcohol (Cosío 4: 79), hecho que recopila Armando Ramírez en Chin Chin el Teporocho para recalcar el antecedente de los primeros teporochos, un grupo de indigentes que pedían un té por ocho centavos, allá por el rumbo de la Lagunilla (Contraportada de Chin Chin), con el ánimo de curar la cruda y calentarse el estómago en las horas más frías de la mañana: “. . p para ir en busca de la señora enrebosada que expendia en su vivienda cafe negro y hojas de naranjo con su chorrito de alcohol de noventa y seis grados" (Chin Chin 16).

Cosío Villegas manifesta que para 1909, "el alcoholismo era común en todas las clases sociales, pero que en la media causaba mayores estragos, y en la baja añadidos a sus trastornos a la mala alimentación, era el origen de muchos casos de tuberculosis" (4: 75). En la segunda década del siglo XX, por orden del Poder Ejecutivo, se prohíbe brevemente la introducción del pulque a la capital. Aumentando su consumo en los años treintas ("De pulquerías" 29). Lo cual ratifica el tepiteño Héctor Romero, al expresar que "hasta mediados de nuestros años treinta, la secular pulquería mexicana retuvo, casi en exclusiva, el privilegio de ser albergue generoso de una manifestación folklórica altamente cotizada por aquellos especialistas que no les escandaliza la mexicana alegría ni padecen el vicio de la abstinencia pulquera" (57). En la misma era, el gobierno mexicano declara la guerra al vino por medio de cruzadas antialcohólicas de parte del presidente Cárdenas. La clausura de cantinas y la historia del alcohol en la capital, aseveran un descenso en el consumo de éste, en años posteriores (La Jornada 1 marzo 97: n. pág.). 
Octavio Paz al analizar el comportamiento del mexicano, entendido ya como fenómeno social de nuestro tiempo, describe: “. . . se emborrachan juntos, se hacen confidencias, lloran las mismas penas, se descubren hermanos y a veces, para probarse, se matan entre sí" (37). Mariano Cuevas al revisar los escritos de fray Toribio de Benavente, reveló una vez más, ciertas conductas durante la borrachera en el México antiguo: "Se herían y se descalabraban unos a otros, y acontecía matarse y aunque fueran muy amigos y propincuos parientes" (1: 131). Ambas opiniones, concuerdan con lo que ocurre en la novela Chin Chin el teporocho.

Hasta aquí, historia y crónica recopilan los antecedentes históricos del alcohol en México, su paulatina aceptación, control, comercialización y desmedida ingestión en la capital mexicana, a través del tiempo y la costumbre, generando así un determinado estilo de vida alcohólico en Tepito. De tal forma, este previo estudio, coadyuvará a una mejor comprensión del inherente impacto social del alcoholismo presentado por Armando Ramírez. 


\section{El contexto de la violencia}

La violencia de índole verbal y física en Chin Chin el teporocho, por lo regular siempre es consecuencia del consumo excesivo del alcohol, y aparece en esta obra como un elemento intrínseco en el habla y comportamiento del protagonista y un extenso número de tepiteños. A la par, es una proyección resultante de la asombrosa marginación económica y social que circunda muchas zonas del Distrito Federal, y en este particular caso a Tepito, un lugar con muchísimo ímpetu, debido al influjo que el alcoholismo ejerce sobre las existencias y vaivenes de muchos de sus habitantes.

Para poder entender la explícita violencia del texto como un producto social inducido por la ingestión desmedida de bebidas embriagantes en el barrio de Tepito, es necesario remontarse a los orígenes históricos y respectiva formación del lenguaje popular, ya que éste, es el instrumento de agresión y defensa en general entre los borrachos y dipsómanos presentes en Chin Chin. Primeramente, es pertinente indicar el análisis del crítico literario Angel Rama, en cuyo examen del período colonial en la ciudad de México, apunta la existencia de una opulenta ciudad letrada, en extremo agresiva e insensible hacia la plebe, integrada por léperos alcoholizados y otros individuos de similar estirpe. En la capital, el habla cortesana de un grupo reducido de burgueses europeos y criollos que apoyaba y justificaba el poder de la Corona, siempre estuvo en contra del habla popular empleada por el lumpen urbano como medio de comunicación: 
[Desdeñaban] su algarabía, informalidad, torpeza e invención, cuya libertad identificó con corrupción, ignorancia, barbarismo. La evolución de esta lengua fue constante apelando a toda clase de contribuciones y distorsiones, y fue sobre todo regional, funcionando en áreas geográficas delimitadas. (25-44)

El ensayista Carlos Monsiváis nos informa que aún en la tercera década del siglo XX, los académicos de la Lengua, "señalan imperfecciones y monstruosidades, y vierten regaños sobre el vulgo que, con tal de envilecerse, se revuelca en los barbarismos" (La Jornada, 17 abril 1997: n. pág.).

En base a los criterios anteriores, y de acuerdo al contenido textual de la novela, los beodos y escasamente sobrios personajes de Chin Chin, se expresan, se enfrentan unos con otros, y comunican por medio de esta habla popular que en su desarrollo ha dado forma a lo que actualmente se conoce como lenguaje tepiteño, un agresivo medio de comunicación, conformado por la necesidad de protegerse de la violencia histórica-social interna y externa a Tepito. A partir de aquí, entrevemos el resultado de un proceso forjado durante varios siglos de marginación económica, social y política, tal y como lo reafirma el historiador Enrique Florescano: “De manera violenta y progresiva, el discurso del conquistador impuso un nuevo lenguaje ..." (95). Así se engendra un "mestizaje biológico y cultural" (Lope Blanch 7), que al paso del tiempo integra un sentir y habla peculiar entre la clase baja citadina y consecuentemente en este barrio. Roger Bartra cita al lenguaje tepiteño, y lo clasifica como una forma 
original de defensa, diferenciación e identificación cultural (27). Esta forma de hablar refleja el pendenciero espíritu de solidaridad característico de la barriada, siendo a la vez, un producto de la precaria condición humana del Distrito Federal, y en específico la de esta área geográfica, poblada por infinidad de borrachos y teporochos de todas las edades: “. . . hoy son doscientos, mañana, quizás cien o a la mejor trescientos, todo es cosa de cómo se van muriendo en las madrugadas ..." (Tepito 118-119). Entre la vida y la muerte, estos tepiteños, y muchos más, utilizan expresiones, gestos y modales abruptos que invitan a desentrañar situaciones y patrones de conducta de apariencia pueril y simple, pero que en lo recóndito poseen una complejidad semántica sorprendente. Sus raíces culturales son muy profundas, y consecuencia de un antiguo desdeño social (Tepito 14).

La violencia en el habla de gran parte de los personajes, tiene una serie de características que se relacionan y reverberan la popular figura histórica del naco:

Naco dentro de este lenguaje de discriminación a la mexicana, equivale a proletario, lumpenproletario, pobre, sudoroso, el pelo grasiento y el copete alto, el perfil de cabeza de Palenque, vestido a la moda de hace seis meses ... el acento golpeado ... la herencia del peladito y el lépero .... (Monsiváis, Días 120)

En Chin Chin, aparece este personaje contemporáneo, con todo su linaje histórico, siendo reconocido en el Distrito Federal con tal infame sobrenombre. El naco es personificado por Rogelio y la mayoría de los 
tepiteños, quienes al ser nacos, son consecuencia evolutiva de dos personajes típicos en la historia de la capital mexicana: el lépero y el pelado. El primero ha sido considerado durante varios siglos, además de afecto al pulque (Cumberland 173), "villano, vil, malicioso, procaz, desvergonzado, atrevido, obsceno" (Santamaría 661). "El lépero, generalmente hablando, como para caracterizarse de pura sangre, ha de ser mestizo, bastardo, adulterino, sacrílego y travieso, entendiéndose que más que picardía debe haber chispa o ingenio en el magín ... " (Prieto 87). Y al pelado, lo describe Samuel Ramos como figura clásica de finales del siglo XIX y principio de éste. Fue también adicto al alcohol y muy popular:

$[P]$ ertenece a una fauna social de categoría ínfima y representa el desecho humano de la gran ciudad. En la jerarquía económica es menos que un proletario y en la intelectual un primitivo. La vida le ha sido hostil por todos lados, y su actitud ante ella es de negro resentimiento. Es un ser de naturaleza explosiva cuyo trato es peligroso, porque estalla al roce más leve. Sus explosiones son verbales y tienen como tema la afirmación de sí mismo en un lenguaje grosero y agresivo. (54)

En Chin Chin, el teporocho presenta características muy similares a las del pelado, pues pertenece al lumpen del proletariado, y su existencia ha estado también rodeada por la violencia y el fatalismo extremo de la vida urbana. Chin Chin es una persona que sabe defenderse ante cualquier tipo de ataque, ya sea físico o verbal. Es un hábil peleador y 
maestro del verbo callejero, su lenguaje también es grosero, agresivo e influido por el alcohol y su medio ambiente, pero difiere del pelado en su contexto, ya que Rogelio sí es una persona inteligente y consciente de su problemática social.

En general, al pelado se le cataloga como a un tipo sin dinero, "de las clases bajas, harapiento, mísero e inculto, pero por lo común simpático. En sentido figurado, persona de mala educación que acostumbra lenguaje o modales obscenos" (Santamaría 824). En un estilo actual y sofisticado, Chin Chin y muchos más, integran "la generación de la caguama" (Chin Chin 100), ${ }^{5}$ y presentan características afines con el lépero y el pelado, capitalinos que en sus respectivas épocas conformaron la generación del pulque. De este modo, Ramírez describe la vida de varios nacos que gustan del vino y están acostumbrados a deambular a diario entre la violencia física y verbal de la barriada, proveniente del alcohol. A pesar de ser borrachos, son personas astutas que han aprendido a defenderse, sobre todo por la necesidad de sobrevivir en un medio que los acecha con toda clase de agresiones corporales y vituperios. Éstos, además de batirse con los puños, piernas y cabeza, señala el escritor, tienen ". . que saber bailar el oso, en círculo, cuidando de que la patada a los lugares nobles, santos y bendecidos no profane y abusado con el cabezazo ..." (Tepito 33). También se encuentran a diario, ante el inminente acoso de los albures callejeros: un "juego de palabras de doble sentido" (Jiménez 1), "que tanto se practica en la ciudad de México" (Paz 27) y en Tepito.

5 Caguama: Cerveza de tamaño familiar, de marca Carta Blanca, Corona, Superior y Tecate. A quart of beer (Gutmann 175). 
- tu dime la verdad ¿a poco no soy buenaso para los albures?

— se nota lo enzarto bonito.

- yo te ensarto mejor.

— ¡ah! ¿ya nos llevamos a alburearnos?

- pues tu chavo, que me querias alburear, que dijiste este chile en papas yo me lo embarro. (Chin Chin 125)

El albur, lo define el premio Nobel mexicano Octavio Paz, como una contienda oral de carácter público o privado; una batalla popular estructurada por alusiones obscenas, mediante las cuales los contrincantes se atacan verbalmente por medio de la improvisación de inteligentes trampas y combinaciones lingüísticas sorprendentes. El objetivo es vencer y confundir al enemigo, perderlo y enmudecerlo por medio de palabras, expresiones y ademanes rapidísimos e ingeniosos. Los vocablos que se utilizan poseen connotaciones sexuales hostiles; el perdedor es penetrado, humillado y violado por su contrincante (27-8).

- presta ¿no?

- toma

- ¿mame usted?

- biscocho, ya dije, ya no juego, te gane, te lleve al hotel, te arastre por la cama, y gritaste y hasta dijiste hay, te abandone porque las sabanas del hotel las manchaste de sangre.

- ni modo me ganaste lo reconozco hijo, ¿que ya le vas a caer al callejon? (Chin Chin 124-25) 
En relación al albur, la ensayista Margo Glantz opina que "ha representado una forma de lenguaje vinculado a barrios proletarios y de lumpen. Es un lenguaje que equivale a una germanía y como tal es producto de un tipo de hombre que en México se ha llamado lépero, luego el pelado ..." (257). Añade Ramírez: "Hablar de Tepito es hablar del lenguaje y las últimas consecuencias en el trastocamiento del concepto de las palabras" (Tepito 13).

A imagen y reminiscencia de los ya referidos léperos, pelados y nacos, la agresión verbal comienza en Tepito, "bajo la excitación del alcohol" (Chin Chin 34), así jóvenes y adultos achispados, se saludan y conviven con palabrotas cuya violencia semántica aumenta al brindar asiduamente con toda clase de bebidas alcohólicas, gestos corteses y grotescos. Rogelio y compañía, pasan por la vida, soñando y añorando lo imposible, bajo la sensación del licor y la respectiva cruda; desatendiendo el presente mediante el recurso de la verborrea. Su constante borrachez y fracaso personal provoca una fusión incesante de vocablos groseros, vulgares y agresivos; a veces lúgubres o retorcidos; términos que se disipan y perecen en la oquedad o grandeza de la plática callejera y en el chisme de los estrechos y muy humildes cuartos de vecindad. El lenguaje tepiteño sirve de vehículo para manifestar una serie de sentimientos y vivencias impregnadas por un estilo de vida que emana de esta zona depauperada, exponiendo un modo de vida donde prevalecen las actitudes pendencieras, desarrollándose y repercutiendo socialmente bajo los efectos etílicos. El relato revela un ambiente cargado de cierta indolencia familiar; con teporochos albureros, cábulas, obreros crudos y 
borrachos gandayas que se dedican a amedrentar a las bellezas femeninas de la barriada. Hostigándolas con leperadas, manoseos, golpes e insultos: - uy pos si trais padrote, sabes que ñero, dale chance que se gane unos pesos, es rapido nos vamos al hotel y te la regreso, me dice el viejo riendose. (41)

Consecuentemente, se percibe una forma de vivir indolente y brusca, que se agrava entre las copas y botellas. Por eso, Octavio Paz también ha observado que en nuestro lenguaje existen "[p]alabras malditas, que sólo pronunciamos en voz alta cuando no somos dueños de nosotros mismos" (64), al estar intoxicados de alcohol e ira que se desparrama en voces y expresiones crueles y provocadoras que emanan de bocas ebrias e hirientes; palabras que en determinado momento pueden costarnos la vida: “. . hasta donde un mexicano es capaz de aguantar, a donde uno se muere en la raya -eres puto y vas y chingas a tu madre-" (Chin Chin $41)$.

En el transcurso de la trama, la bebida en abundancia contribuye a enfatizar más el albur y las groserías del lugar, dando como resultado acciones agresivas y en extremo rudas. Así, se reafirma el carácter y reputación del barrio: ". . p por eso soy poca madre, para los ojetes" (Chin Chin 114).

Este tipo de habla, a veces es una representación de la frustración personal y la miseria que rodea a muchísimos tepiteños, sobre todo al teporocho, maestro del lenguaje y de la vida del barrio, casi consumido por la constante ingestión de bebidas alcohólicas y la brutalidad circundante del ámbito social. 
En diversas ocasiones, la novela presenta situaciones dramáticas, impulsivas y naturalistas, resultado de la dipsomanía, tales como la presencia de Chin Chin: "alcohólico, sucio y de edad indeterminada" (Brushwood, La Novela 67), las grotescas apariciones de Gilberto, y la posterior muerte del primo hermano del teporocho:

- si ayer andaban chupando el y luis en el coche, me invitaban pero yo ya no tomo ... (96) ... . se lo llevaron en una camilla como quien carga leña, se lo llevaron y le hicieron una autopsia y lo restregaron con un cepillo y lo lavaron con agua salida de una manguera y olio a formol... . (98)

Maxim Newmark en el Dictionary of Spanish Literature define al naturalismo como sistema filosófico que atribuye todas las causas a la naturaleza o al medio ambiente como primer principio determinista. Agrega que su teoría literaria fue formada por Emile Zola en Le roman expérimental, en el cual, el novelista es considerado un impasible técnico de laboratorio que registra datos del comportamiento humano dentro del contexto de un determinado ámbito social (236) (Trad.). Asimismo, nos indica el profesor David Baguley que el naturalismo es una deterioración paulatina del carácter que conduce a condiciones excesivas de la privación del juicio: "histeria, manía homicida, brutalidad, degradación física y mental," y alcoholismo que libera a la bestia inherente a cada ser humano, perdiéndose la razón, el orden y la integridad, reflejando de esta manera una visión patológica de la vida (48) (Trad.). De esta forma aparece en Chin Chin con todas las características referidas: 
... y desvarias y tu pensamiento ya no te obedece y divaga como anima en que ya te da lo mismo, morirte, que cagarte con los pantalones puestos o tragar en un basurero junto a la mierda con moscas a su alrededor $u$ orinarse en las calles del centro de la ciudad frente a un policia y contestarle que esta regando a las florecitas, .... (73)

De acuerdo al naturalismo, el ser teporocho es una consecuencia de la "herencia, el ámbito y el momento en el tiempo" (Minogue 11) (Trad.). ... una extraña sensacion invade mi cuerpo, un sudor en mi espalda aparece, siento desasosiego, pienso en mis padres, apenas si me acuerdo de ellos, a veces siento como si se me fueran aparecer, y yo no quiero verlos, .... (Chin Chin 31)

Debido a que no existe solución inmediata a su problemática, los personajes ramireanos experimentan una serie de situaciones sociales de carácter triste y complejo. Algunos beben con frecuencia para escapar y reprimir de momento la angustia personal y la cólera de una atmósfera citadina plagada de acciones físicas violentas y fulminantes. Esta belicosidad casi siempre exacerbada por el alcohol, se complementa con la violencia oral, y en consecuencia: "Toda la angustiosa tensión que nos habita se expresa en una frase que nos viene a la boca cuando la cólera, la alegría o el entusiasmo nos llevan a exaltar nuestra condición de mexicanos ..." (Paz 65). En Chin Chin, Ramírez refuerza y ejemplifica lo expresado por Paz:

- ¡viva mexico hijos de la chingada! - y algun borracho empistolado hecha bala al cielo con una actitud retadora, 
toda la noche tomamos vino y bailamos y nos peleamos al calor del alcohol y las fogatas en las vecindades o en los callejones, humean las paredes; ... . (112)

En la novela, por medio del fenómeno de la alcoholización frecuente, prevalece un alejamiento de la realidad, con plena conciencia personal, ante la terrible y adversa circunstancia diaria: ". . p para calmar su sed su vicio, sus nervios, su cerebro, su espiritu, callar su conciencia y huir de la realidad" (58).

Para Chin Chin y demás teporochos, el ". . alcohol de noventa y seis grados revuelto con refresco de uva o de naranja ..." (72), apacigua el dolor causado por los golpes de la vida, físicos y mentales, producto de las peleas callejeras y las amargas experiencias familiares. La teporocha "... es bebida que adormece, a los sufrimientos, las penas ..." (72). Es un eficaz y económico remedio para aquellos que osan probarla sin resistirse a su encantadora mezcla, con el objetivo de provocar el olvido y alejamiento temporal de la inmensa y virulenta urbe:

... porque la mole, el mounstro, el gigante citadino, el hombre de carne y concreto nos ha devorado con un grito ensordecedor, con su rapido movimiento con su indiferencia aterradora. (26)

El investigador Matthew C. Gutmann, al hacer hincapié en la situación demoledora del alcoholismo, ha dicho que la bebida y la violencia han estado asociadas por mucho tiempo en las colonias populares del Distrito Federal. La percepción popular incluye a éste, como causa inmediata y raíz de muchos episodios violentos que involucran a 
maridos, hermanos, y a otros (193) (Trad.). Entre estos otros, Chin Chin, Rubén, Víctor y Gilberto son integrantes de un ambiente en el que el vicio propicia y conduce a la dipsomanía y su inherente violencia, encaminándoles hacia un determinado estilo de vida en extremo pendenciero. El estrecho vínculo de camaradería que les une es afectado por la influencia de esta enfermedad que exacerba las diferencias entre amigos, contribuyendo a la progresiva exterminación de Víctor, quien bajo la influencia de la bebida, agrede verbal y físicamente a Rubén:

- ¿que güey te quieres aventar un tiro conmigo?

- vas victor, desde cuando te traigo ganas.

- pues vas pinche ojete - acepta victor el reto a pelearse. (56)

Como consecuencia, Víctor es víctima de una traición espantosa por parte de Rubén, quien logra asesinarlo, después de embriagarle en una parranda. En este contorno social, el espíritu del vino es aliciente para fraguar la venganza contra el asesino de Víctor: "-por victor - brindoyo se manito, a mi me late quien fue el que te hizo la travesura, pierde cuidado que por alla te lo mando" (99).

Simultáneamente, la bebida sirve para esterilizar el exterior del cuerpo y apaciguar el coraje provocado por la beligerancia:

... ruben con hilillos de sangre corriendo, por su pecho, le dio un gran trago a la botella, de a litro de tequila que traian, despues vacio un poco sobre su pecho, para lavarse los rasguños.... (115) 
Más tarde, Chin Chin venga la muerte de su primo, matando a Rubén. La novela refleja el hecho de que el alcohol "es principal causa de muerte entre la población de 15 a 34 años" (Gaceta UNAM 1 abril 1993: n. pág.). Al mismo tiempo, Matthew Gutmann señala al homicidio de hombres en edad productiva, como uno de los principales efectos indirectos del alcoholismo en México (175).

Sin lugar a dudas, en Chin Chin el teporocho existe una cadena de situaciones violentas que surgen y evolucionan en torno al abuso y consumo desmedido del vino. Entre éstas, se encuentran las que emergen y departen de la simple y cotidiana agresión verbal, hasta las que conllevan al homicidio. Son consecuencia palpable de la violencia textual que involucra a jóvenes y adultos alcohólicos, relegados en tiempos pasados por la "ciudad letrada" (Rama 23), y en la actualidad por la sociedad culta metropolitana, cuyas élites y lacayos en el poder no permiten el acceso a un mejor nivel de vida para el populacho. Este hecho implicaría inmensas pérdidas monetarias y de control social, ejercitado por medio del constante suministro de alcohol a las masas: ... no, no, no, no, no, chingada madre parece que voy a volverme loco, sin ninguna esperanza, condenado perpetuamente a seguir siendo siempre atraves de los siglos de los siglos un trabajador, ahora un trabajador joven, mañana un trabajador maduro, pasado mañana un trabajador viejo, arrugado, achacoso, viviendo de pura suerte, suerte maldita que vale pa pura chingada. ... (27) 
Pese al violento choque social del alcoholismo en lugares como el Tepito de Ramírez, la voraz actitud de los poderosos continúa capitalizando con el analfabetismo, y promueve la sanguinolenta violencia en el lumpen proletario, sin considerar o respetar en lo absoluto la integridad física y emocional de muchísimas familias, tal y como sucede en esta novela. 


\section{Problemática social}

De acuerdo a diversos criterios académicos, el alcoholismo es un fenómeno de extensa influencia y graves efectos sociales que repercuten en ausentismo laboral, desempleo, promiscuidad sexual, delincuencia y el deterioro de la salud física y mental entre otros. Su cuadro social es un producto vivo, generado por la vehemente dependencia del licor que exterioriza situaciones patológicas con efectos destructivos en la vida social y familiar (Anderson 56). En Chin Chin el teporocho se perciben varias conductas antisociales, resultado de la constante presencia y popularidad del vino en el medio ambiente de Tepito.

"El mundo que Ramírez presenta es un cuadro crudo de una clase social para la que la supervivencia es una lucha diaria ..." (Chiu-Olivares 103). Es un ámbito donde predomina la penuria económica de la mayoría de sus habitantes, quienes sobreviven día a día entre los reducidos espacios de las vecindades y sus modestas viviendas, uno o dos cuartos que son utilizados como estancia, cocina y comedor durante el día, y en la noche como dormitorio (Lewis 427-29).

... Victor se viene a dormir, dormimos en la misma cama, tambien oigo cuando mi prima sube a dormir al tapanco, cuando se apagan las luces, cuando mis tios apagan la television, ellos duermen en la pieza de la entrada que sirve de recamara y de sala, a un lado esta la cocina que sirve tambien de comedor, ahi se queda a cuidar el cachafaz, es el perro,.... (Chin Chin 31) 
En una descripción más realista de la vecindad, explica Armando Ramírez: "Los lavaderos al centro si es la clásica vecindad; los excusados: juntitas las cinco tazas, si está muy jodida; los tendederos formando una maraña con sus lazos sabiamente colocados para que el sol dé a plenitud en los calzones de la del diez que usa talla cuarenta,..." (Tepito 24).

La mayoría de los tepiteños que aparecen en la obra son una extensión del proletariado del Distrito Federal. En teoría social, Argyle explica que la identidad social fluye a través del lenguaje y apariencia, conformando determinadas normas y patrones de conducta (289). Por lo tanto, gran parte del relato presenta a obreros jóvenes y maduros, artesanos, desempleados, empleados, vividores y vagos; teporochos, policías abusivos, amas de casa, chachareros, salderos, las marias ${ }^{6}$, borrachos, e inmigrantes del interior de la República mexicana, y hasta uno que otro extranjero. Tepito, es una comunidad acostumbrada a deambular y "hacer algo de la nada" (Quiñones 43) (Trad.), gente pobre y miserable que se desplaza cotidianamente por las calles del barrio y la ciudad en busca del sustento personal y familiar. Al mismo tiempo aparecen una minoría de individuos pertenecientes a la clase media capitalina: un inmigrante de origen español dedicado al comercio de ultramarinos, sus dos hijas y esposa. El nivel social y económico de esta familia produce envidia y respeto entre la gente de la barriada, quienes les consideran "gente decente y acomodada" (Cockcroft 219):

6 Las marías: vendedoras ambulantes de frutas, cacahuates, nueces, piñones, pepitas de calabaza, chilitos de visnaga, tunas (Ramírez 66), "chitos" (carne de burro enchilada), etc. Las marías pertenecen a diversas etnias de México. 
... ¿sabes quien es su papa? el español, el dueño de la tienda.

- el estanquillo que esta pintado con anuncios de la carta blanca?

- no, sabes cual la vinateria, la tienda de ultramarinos que esta en la esquina y tiene una marquesina de gas neon de la pepsi cola y que en los aparadores tiene anuncios de cigarros Raleigh, y bacardi y del nescafe y de la FUd. (Chin Chin 23)

En ambas clases sociales, la bebida involucra a cada uno de los personajes en la amplia y multipatológica problemática social de Tepito (Quiñones 40) (Trad.), una problemática que aparece en Chin Chin el teporocho, señalando un panorama social deprimente que comprende a todos los personajes de la novela, quienes al encontrarse atrapados en la dinámica de un proceso incontrolable, sucumben o sobreviven dramáticamente. En este caso específico, tal y como lo indica Roger Bartra, "al experimentar viajes más allá de los límites éstos pueden llevar a una autodestrucción; el caso más evidente y espectacular es el alcohol" (La Jornada, 21 julio 1996: n. pág.).

El frecuente estado de intoxicación de Chin Chin va acumulando efectos destructivos físicos y emocionales en su existencia. Le promete a Michele que va a dejar de tomar, pero no puede: Jura con religiosidad que no va a beber alcohol por un año en el perímetro del Distrito Federal, pero no en Tlalnepantla, estado de México (96-97). Quebranta el juramento, y con este hecho, le va "de la jodida con el castigo de diosito" (97). Finalmente, la embriaguez logra separarlo de su ser, la familia, trabajo y amistades (Anderson 56). 
... ya llevo mas de año y medio tomando todos los dias, duermo en el callejon de "salsipuedes", si es que la borrachera me deja llegar, ya me siento cansado y apenas voy a cumplir veinticuatro años, ya nada me importa, ahora soy un empedernido borracho, ya no siento nada, todo ha ido perdiendo valor ante mis ojos, la vida, la muerte ya no significan nada para mi, ya todo es igual, da lo mismo que sea lunes, que sea domingo, .... (153)

A pesar de ser un joven en edad, su semblante y cuerpo muestran un deterioro patético, como si estuviera muerto en vida. Reitera Ramírez: "Ocurre que se es teporocho y ya se achicó la cortedad de la vida" (Tepito 119).

Con respecto al clima social del alcohol, Griffith, et al., en un proyecto auspiciado por la Organización Mundial de la Salud, indican la necesidad de entender los diversos criterios que existen en determinado momento histórico en una sociedad en relación a la bebida, para detectar así los problemas que conciernen a su consumo (75-102). Uno de estos problemas es el ausentismo laboral, por lo tanto es necesario señalar sus causas y origen de acuerdo a la novela. El autor cataloga a Tepito como una comunidad donde hay escasez de recursos materiales y limitado acceso a fuentes de trabajo, los jóvenes del área se ven en la necesidad de laborar fuera del perímetro del barrio como obreros, empleados de gobierno, y en el caso de Chin Chin, Gilberto y Víctor, como dependientes de una cadena de supermercados ubicados en colonias de clase media. Acuden a trabajar con la intención de satisfacer las necesidades básicas 
personales y contribuir a los gastos del hogar, integrándose cada mañana a la anónima masa citadina que invade las calles de la "ciudad más grande del mundo" (La Jornada, 20 octubre 1996: n. pág.). Se desplazan a pie y en transporte público a reventar que asemeja a las latas de sardina. Son partícipes involuntarios de la dinámica de una economía donde prevalece el capital extranjero (116), el cual crea un sistema económico utilitario que explota su juventud y fuerza de trabajo, sin ofrecerles la oportunidad de atender y sufragar las necesidades monetarias que demanda el sustento diario en la capital del país (108-9).

Precisamente, "[o]rillados por el ambiente y la situación en que viven, buscan medios de escape ..." (Chiu-Olivares 103). De esta forma el alcohol se convierte en un instrumento de liberación psicológica ante toda la tensión acumulada por el trabajo semanal excesivo y mal pagado: "pagan veinte pesos diarios" (19). Un salario incapaz de proveer una existencia digna y decorosa:

... ¿sera por eso? que cuando llega el dia sabado y cobro mi raya, me lleno de ansiedad y salgo huyendo, corriendo como desesperado para reunirme con mis amigos, para irnos a divertir, a bailar, a emborracharnos, a buscar una puta, a vivir de verdad aunque solo sea sabado en la noche y el domingo todo el dia. (27)

A medida que transcurre la vida con sus inescapables y sorpresivos golpes y amargas experiencias, la borrachera seguirá siendo un vehículo de escape. Les conduce progresivamente a un estado de enajenamiento del ánimo que al paso del tiempo los separa de la realidad y aleja de toda 
clase de responsabilidad social y personal. Así, la embriaguez propicia un ausentismo laboral constante que se convierte en desempleo, arrastrando a Chin Chin a terminar viviendo en la miseria de la vía pública; a Gilberto y otros sujetos a convivir día y noche, y por períodos prolongados con los teporochos del barrio.

La sobreentendida negativa hacia el trabajo expresada por medio del ausentismo espontáneo, es una reacción que emana del comportamiento social de jóvenes y adultos incapaces y en desgracia, debido a los estragos de las crudas físicas y morales ocasionadas por el vino y los problemas de adaptación social o familiares. La investigadora Paulina Fernández aclara que durante esta etapa histórica, el incentivo económico de la clase trabajadora es casi nulo ante el esfuerzo agotador del ser y la remuneración ridícula del salario mínimo (Fernández P. 13: 215): "un sueldo por debajo del mínimo" (Chin Chin 19). Así cuando Rogelio es despedido de su trabajo, no se enoja y tampoco desea afrontar la realidad: "- el lunes voy a ir a buscar chamba en otra compañia de supermercados, pero por ahora hay que olvidarnos de los problemas y vamos ha chupar" (101).

El alcoholismo además de interferir en las relaciones sociales normales, y reducir la habilidad personal para mantener un empleo, conduce al individuo a la asociación con otros alcohólicos (Brain 153). En la trama, hay un número indefinido de sujetos que se dedican por completo a la embriaguez, habiendo abandonado empleos y familias. Éstos, como hijos de la calle, logran sobrevivir milagrosamente el calvario de cada día. Además, se encuentran alejados y discriminados por 
la sociedad de la cual, en un día tal vez no muy lejano, formaron parte activa como miembros o jefes de familia y como trabajadores. Estos teporochos aparecen por doquier, su presencia y forma de vida genera seguidores; desde el Pifas y Gilberto, hasta Chin Chin. El resultado de ser teporocho es devastador: “. . . ser teporocho es llegar a ser nadie, es no importarte nada, ni tu vida, ni tus hijos, ni tu esposa, es perderlo todo, es llegar a no tener ni madre" (73). Al punto que, el alcohol y la vida los ningunea.

El implícito desempleo en el texto, en ciertos casos es consecuencia del ausentismo laboral, y en otras ocasiones se debe a la prepotencia de los patrones y gobierno, quienes condenan a individuos y en algunos casos a familias enteras a la miseria; familias que padecen estragos debido a la falta de un ingreso fijo. El círculo de pobreza donde subsisten se agudiza y acrecenta, forzándolos a sobrevivir del ingenio y en ocasiones, de la caridad de vecinos y familares. Así encontramos el caso de "Jose el Pifas" (27) quien merodea su antiguo hogar, siempre borracho. Gilberto, el hijastro de éste, al ser despedido de su empleo injustificadamente, y cansado de los muchos problemas en su casa, se dedica a beber hasta llegar a ser casi un teporocho, mientras sus hermanitos y su mamá quedan sujetos a la buena o mala fortuna:

... pues ya me corrieron de donde trabajaba.

- te encontraron haciendo algo malo?

- no hicieron reajuste de personal.

- pero te indemnizaron con tus tres meses ¿no? 
- no, nomas me pagaron lo de mi semana, un señor me dijo que me fuera quejar al sindicato, pero ahi que me tiran de a loco con eso que se creen mas que los patrones. (47)

En relación a la promiscuidad sexual, el narrador introduce escenas donde el susodicho comportamiento es inducido por el espíritu del vino, y compete tanto a adultos, como a jóvenes. La madre de Gilberto, apodada la Pindonga o doña Chole se convierte en la primera amante de Víctor, también seduce a Chin Chin, y el Pifas, su ex marido, la golpea y la usa para satisfacer su apetito sexual cada vez que está ebrio (27).

Claramente, el alcoholismo los conduce a la degeneración y a la pérdida de valores morales (Chiu-Olivares 103). Bajo el estupor del licor, la gente joven frecuenta cabarets y fiestas para conocer señoras maduras y mujeres jóvenes apegadas a la vida alegre. A la vez organizan orgías con algunas de las muchachas del barrio:

Ya en el departamento de ruben comenzamos a tomar y a emborracharnos y a bailar, ruben y guadalupe se metieron a la recamara y gilberto baila muy apretadito con lilia, se besan y toman del mismo vaso, mientras alma y rodolfo quien sabe que tanto se dicen que se rien en la tina del baño, en donde estan tomando de la botella a la boca, el vino solo, .... (Chin Chin 53)

En Chin Chin aparece a la par con el alcohol, el gusto por la mariguana y el tráfico abierto de ésta en el vecindario: "— vas maestro chupa limon-" (15). Las demandas sociales y económicas para tener acceso al vino en la estrecha comunidad de Tepito, contribuyen a que 
Rogelio delinca al vender esta droga (69-74). En el Tepito de Ramírez, el fumar mariguana es un hábito y vicio complementario a la vida social de muchos jóvenes y adultos que gustan de su efecto intoxicante, y se dedican a fumar en la calle o fiestas, la combinación de "hojas y flores secas" que esta planta produce (MacDonald 21). Para poder "... visitar a todas las galaxias habidas y por haber ..." (Chin Chin 16).

... se ocultan unos jovenes de ambos sexos, fuman marihuana, el viento fresco trae consigo el olor a yerba quemada, petate consumiendo por el fuego, y el sonido de succion cuando fuman, ssssss y luego la expulsion fuffffff. ... (30)

$\mathrm{Al}$ ser ilegal el tráfico de esta yerba, Rubén y Chin Chin son arrestados por la polícia, se les acusa de cometer delitos contra la salud, para más tarde ser puestos en libertad debido a que pagan una mordida $(44,138)^{7}$

Ramírez enfoca la premeditación del oportunismo económico en Rubén y la figura del español, una pareja de sujetos inescrupulosos, y responsables de sacar el poco dinero a la gente del barrio con la venta de la mariguana. Además, el español es un importante proveedor de licores en cierta sección de Tepito:

${ }^{7}$ La mordida es una cantidad de dinero que se paga a las autoridades para sobornarlas y salir de un problema determinado. "Mordida. Spanish word literally meaning "bite." In Mexico it refers to a bribe paid to government employees" (Briggs 150). 
$\mathrm{Al}$ salir de la tienda [del español] gilberto me arrebata la botella y se la empina - no le tomes solo te vas a emborrachar rapido- le digo.

- no importa -me contesta volviendose a empinar la botella

- lo que quiero es olvidar, adormecerme. (48)

De tal forma, las ventas de licor contribuyen a la confusión, el delirio, las alucinaciones aterradoras y severos temblores del delírium trémens, (Dawson 1:22) y a la degeneración física y mental de muchos habitantes de Tepito. Entre ellos, Chin Chin narra parte de su odisea hacia la nada: ... uno se emborracha uno o dos dias, luego una semana o quince dias y al final del camino, todos los dias, hasta que uno se muere de congestion alcoholica o una cirrosis hepatica o de alguna enfermedad venerea o ya de plano porque uno no sirve ni pa'maldita la cosa, ya cuando se te hinchan las piernas, el rostro se te abotaga, la nariz se vuelve roja, los pomulos se saltan y las mejillas se sumen y el vientre se abulta hasta parecer una señora embarazada y desvarias y tu pensamiento ya no te obedece y divaga como anima.... (73)

Todos los trastornos psicosomáticos explícitos e implícitos del protagonista y los demás alcohólicos en la novela, son enumerados en Harrison's Principles of Internal Medicine: daño al sistema nervioso central a través de la pérdida repentina de la memoria por medio de apagones que desorientan y confunden. A un lado de los efectos 
maniaco-depresivos, aparecen la tristeza intensa y ansiedad, además de alucinaciones y paranoia. Un extraño cosquilleo se desplaza por el cuerpo entumeciéndolo; hay dolor e inflamación de músculos, incluyendo al esófago y el estómago, ya después vendrán las úlceras, diarreas y sangrado intestinal. El páncreas y los riñones se niegan a seguir funcionando adecuadamente, mientras el hígado desarrolla hepatitis y cirrosis; disminuye la potencia sexual, y la escasa producción de glóbulos rojos y blancos es causa de anemia, infecciones y hasta cáncer (2420-25). La destrucción del núcleo familiar es resultado de la embriaguez, y casi todos los personajes ramireanos se ven afectados con la desintegración de varias familias y vidas. Rogelio es víctima de la fatalidad que genera esta enfermedad, al perder a su primo hermano y alejarse de su primera y segunda familia. En su existencia ya no habrán primos, ni tíos, esposa, posible hijo y amigos, sólo el consuelo y refugio de la teporocha. Sus tíos han perdido por causa del licor a dos hijos, a él y Víctor. "Michele, su mujer, rehusa irse con él para seguir a su padre y a consecuencia de esto, Chin-Chin pasa a formar parte de los teporochos ..." (Chiu-Olivares 98). Para colmo, hasta la homosexualidad del español está relacionada con el ámbito del alcoholismo, y es desenmascarado por Rogelio y Agnes ante Michele: ". . es un depravado ambicioso, vicioso contra el que no podemos hacer nada - termina de hablar agnes muerta moralmente" (148).

Mientras tanto, los borrachos y teporochos del barrio, entre copa y copa, botella o teporocha, piensan de vez en cuando en la familia que cierto día existió y de la cual fueron parte, seguramente muy importante. 
En la esfera ramiriana, la marcada adversidad del medio ambiente indica la inexistencia de una posible solución ante todo el conjunto de circunstancias nefastas asociadas con el delírium trémens. Los acontecimientos previamente señalados, y en base al criterio del psicólogo Eastman, establecen la influencia directa del alcoholismo con toda una serie de problemas sociales cuyo impacto económico, físico, psicológico, ocupacional, interpersonal y familiar prevalece, lo cual se corrobora de la primera hasta la última página de esta novela.

Indudablemente, Armando Ramírez exterioriza toda una alarmante problemática social contemporánea de índole casi universal; existente no sólo en el perímetro de Tepito y la novela, sino en gran parte del orbe. En realidad, la desesperanza y tragedia inherentes, repercuten en una manifestación internacional aciaga de la cual es muy difícil escapar o estar ajeno, debido a la poderosa influencia social que el alcohol ejerce en el estilo de vida occidental. El patético cuadro social del alcoholismo en Chin Chin, presenta gravísimas consecuencias, que a lo largo del relato conforman una inescapable desgracia personal y familiar, resultantes de cada una de las proposiciones que integran esta amplia problemática. 


\section{Clases Sociales}

Los personajes de Chin Chin el teporocho presentan una intensidad en "sus problemas sociales; el mayor número, por supuesto pertenece a las clases baja y media, y predominan los menos adaptados" (Leal 34). De esta manera, en la estratificación social de la novela, se advierte la presencia de ambas clases. No obstante a que cada una de éstas posee determinadas características socio-culturales y funciones de acuerdo a su nivel económico, las dos logran integrarse momentáneamente al participar en la dinámica de la barriada, marcando la pauta hacia determinados parámetros de conducta personal y de grupo que involucran aspectos sintomáticos del alcoholismo.

Circuidos por un medio ambiente determinado, estos colectivos tienen parte en una serie de actividades sociales de libre albedrío, en las cuales está casi siempre presente el alcohol. La mayoría de ellos muestran preferencias por una variedad de líquidos, comidas y música que son parte esencial de la borrachera llevada a cabo en estas fiestas y reuniones. En consecuencia, sus incentivos diarios, giran alrededor de una continua celebración, parte inherente y vital a los ritos, pasajes y comportamiento cultural de Tepito y el Distrito Federal.

Al hablar de los elementos imprescindibles de la fiesta mexicana de barrio, es imperativo incluir la tradición de la buena mesa y música.

Desde fray Bernardino de Sahagún hasta Armando Ramírez, crónica, historia y relato conjuntan en agudas observaciones, la evolución y 
desarrollo culinario en la ciudad de México durante un poco más de cinco siglos. En México a la carta, se muestra una visión del mundo precolombino, donde y en base a la crónica de Sahagún, los que eran ricos cantaban y bebían pulque para honrar a sus dioses y parientes muertos; mientras los pobres únicamente ofrecían comida a las deidades mexicas y a sus difuntos. Igualmente, se menciona en este libro que la poesía de Bernardo de Balbuena en Grandeza mexicana, también reproduce en parte los efectos y características de la vida social urbana, pero la de otro siglo, el XVII:

La verde pera, la cermeña enjuta, las uvas dulces de color de grana y su licor que es néctar cicuta.

Más tarde, Humboldt observa y comenta el fenómeno de la embriaguez y hábitos alimenticios de los nuevos mexicanos. Otros viajeros como Emile Chabrand y la marquesa Calderón de la Barca, relatan sus experiencias y el ritual concerniente a las comidas para pobres y ricos. Ya en pleno siglo XX los platillos y brindis en México todavía causan asombro, comentario y deleite a los nuevos visitantes del Viejo Continente. Admirados, describen con detalle la actividad culinaria popular (Romero e Iturriaga 4: 34-58).

El pueblo capitalino de la Nueva España, para defenderse y sobrevivir los estragos del alcoholismo y su respectiva resaca, adapta y combina a su gusto y por necesidad, desconocidas especias, frutos, carnes y semillas de otros confines, traídas por los españoles. El mestizaje de "la cocina indígena y española" produce ideas gastronómicas exóticas, que 
resultan en lo que actualmente se conoce como "la cocina mexicana" (Romero e Iturriaga 4: 7). Todo este grupo de antojitos, guisos y sopas, aparecen en el relato de Armando Ramírez; un extenso número de platillos que son degustados a diario en el barrio de Tepito. Éstos en unificación con la bebida de agrado personal y el embrujo de diversos ritmos musicales, amenizan la reunión o sirven para curársela al día siguiente y poder continuar bebiendo hasta agotar los límites de resistencia del organismo.

El bullicio que describe Ramírez, representa toda una tradición social resultante del mestizaje en el país. El historiador Serge Gruzinski ha expresado en entrevista que "la ciudad de México se caracteriza por ser un lugar donde culturas y grupos se mezclan. Aquí los mundos chocan, se enfrentan, se entrelazan" (La Jornada, 20 octubre 1996: n. pág.). En Chin Chin el teporocho observamos a un sector de una nación apasionada por la juerga, que en la actualidad, se ha logrado envilecer, y por ende casi apartar de sus respectivas tradiciones culturales, distorsionándolas con la incesante alcoholización, promovida en este particular caso para beneficiar los intereses mezquinos de la oligarquía integrada por conquistadores extranjeros y su descendencia. Así vemos aparecer en el texto una lista muy extensa de productos alcohólicos destinados a satisfacer la demanda y el gusto de determinadas clases sociales: botellas de coñac Martell si hay holganza económica, y brandy San Marcos, tequila, o una botella de "batman" ${ }^{8}$ si no hay mucho dinero. El negocio del

8 En lenguaje tepiteño, se hace referencia al ron Bacardí, ya que el logotipo de su etiqueta, tiene una especie de murciélago. 
embrutecimiento etílico de las nuevas generaciones de Tepito, es muy lucrativo y representa un control social de la juventud sumamente efectivo:

En el saguan de la vecindad, encontramos a gilberto el raton en cuclillas y con los brazos cubriendose el estomago, estaba tembloroso.

— ¿que tienes? - le preguntamos

- es la cruda, no tengo para curarmela

Ruben saca un billete - pongo veinte pesos para el pomole pido diez pesos a victor y diez pongo yo. (51)

Chin Chin y compañía socializan y se intoxican en la calle, en el zaguán de la vecindad, en sus modestas moradas, baños de vapor públicos, cantinas, burdeles, reuniones espontáneas y fiestas de vecindad. En cada una de estas ocasiones abusan de diferentes clases de bebidas espiritosas, las cuales varían de acuerdo al presupuesto del momento, estado de ánimo, horas del día y circunstancia. Así que, el tequila, brandy, ron, cervezas, caguamas y teporochas están sujetas a una lista de ingeniosas mezclas de líquidos como el brandy con refresco de tamarindo, y los fulminantes submarinos, una revoltura de cerveza con tequila.

Por lo regular, el alcohol lo beben sin alimentos, aunque en algunas ocasiones lo acompañan con comida típica mexicana de bajo costo, con la intención de aguantar la juerga y también como efectivo remedio para combatir el malestar que queda después de haber ingerido vino en demasía. Tal es el caso de la pancita, platillo producto del encuentro de dos mundos; combinación acertada de chile guajillo, 
jitomate, cebolla, ajo, orégano y jugo de limón, con estómago troceado de vaca. Francisco Santamaría lo señala como un guiso de arraigo popular en el Distrito Federal, el cual se sirve en "puestos públicos para trasnochadores y parranderos" (795). Y no pueden faltar los picosos chilaquiles, verdes o rojos, "platillo hecho a base de tortillas de maíz despedazadas y cocidas en caldo de chile con epazote, cebolla, queso, etc.," (Cabrera 69).

En relación al gusto del pueblo capitalino y gente de Tepito por varios platillos con efectos curativos, Ramírez es específico: “. . . otros van a los establecimientos de antojitos, a las migas ${ }^{9}$, enchiladas, pancita, pozole $^{10}$, birria $^{11}$, chilaquiles; para "curarsela" " (Chin Chin 112), cuando "la cruda está como para sacar fuego por la boca" (Tepito 77). Los referidos alimentos, son complementos perfectos para curar la terrible resaca del alcohol, cuando uno se siente "bien jodido" (Chin Chin 135). Algunas de estas comidas tienen origen prehispánico, y al paso del tiempo han sufrido su respectiva transformación culinaria. Hoy en día, integran una descripción gastronómica del México antiguo y contemporáneo, sobre

${ }^{9}$ Sopa popular y originaria de Tepito. Es un remedio para aliviar la cruda. Es hecha a base de pan de bolillo, huesos de puerco, longaniza, chile cascabel, huevos. En el caldo, se agrega orégano y chile piquín al gusto (Tepito 81).

10 Guiso de origen náhuatl "(Del azt. pozolli.). Guisado que se hace por lo común con cabeza de puerco, cociendo maíz en un caldo condimentado, hasta que revienta y forma una especie de espuma" (Santamaría 886).

11 "Carne de borrego o de chivo, preparada a semejanza de la barbacoa" (Santamaría 135). 
todo al haber adquirido la categoría de manjares, entre los borrachos, alcohólicos y bebedores achispados. Además, son nutrientes y económicos platos que en determinado momento coadyuvan a recobrar el ánimo perdido - como ya se ha indicado- por la embriaguez, y apresuran la eliminación de los malestares posteriores a la intoxicación resultante de la última reunión social, tales como la naúsea, temblores y calofríos, mareos, vómitos, dolores de estómago, cabeza, cuerpo en general, y depresión psicológica y moral (Chin Chin 135).

En forma general y en relación con el tópico de las reuniones sociales de todo tipo, como las que suceden en Chin Chin el teporocho, en El Peregrino en su Patria, Paz describe acertadamente a éstas, desde una simple reunión o fiesta de barrio, hasta una celebración a nivel nacional. Su crítica y profunda visión expone la soledad de individuos sumamente pobres, y de otros con escasos o muchos recursos económicos, cuyo amor y adicción por las pachangas les conduce a un viaje inusitado. Cuando logran reunirse bajo cualquier excusa a celebrar hasta el acontecimiento más insignificante, toda esta gente participa e integra una masa anónima sujeta al alboroto del momento. A medida que transcurre la reunión o fiesta, las clases sociales se desvanecen y fusionan con amplia libertad en el momento en que los participantes establecen sistemáticamente un comportamiento que va de acuerdo a la circunstancia del lugar, contraviniendo de esta manera las normas sociales impuestas por la cotidianidad del ámbito donde coexisten. El grupo rompe con la rutina diaria por medio de una serie de conductas sorpresivas, inesperadas y antisociales. En algunas de estas actividades prolifera un desorden 
progresivo, extremo y antagónico a la mesura social de la vida del lugar y sus habitantes. La celebración culmina en canto desafinado, euforia y alaridos descompasados, acompañados regularmente por injurias y esporádicos vómitos que se derraman y esparcen ya muy entrada la madrugada. A veces, la alegría del festejo - como ya se ha mencionado anteriormente- se trueca por riña sangrienta; las palabras y expresiones de uso común son substituidas por graves insultos, acompañados de acciones donde la barbarie predomina y se expresa con golpes y lesiones; repercutiendo ocasionalmente en homicidio. "Ella nos lanza al vacío, embriaguez que se quema así misma, disparo en el aire, fuego de artificio" $(36-42)$.

En Chin Chin el teporocho se exponen ambientes sociales típicos de la urbe y la vida de barriada, en donde amigos y extraños se reunen a libar con cubas y cervezas; después de algunos tragos, ya sin considerar el nivel socio-cultural de los invitados, y excitados por el alcohol, bailan con destreza diversos ritmos afroantillanos, ya sea en la comodidad que provee un moderno departamento o en los pasillos y patios de vecindad. Ante la exaltación y ritmo de la música, "tibiri tabara, tibiri tabara" (Noche 76), giran bailando de un lado al otro en la improvisada pista de baile, desplazándose en los brazos de bellas jovencitas y mujeres maduras, con la elegancia y maestría que sólo la práctica y el amor por la diversión y el vicio de las copas puede enseñar. El olor a mariguana aunado al vino ameniza el ambiente festivo. Así, parte de esta gente se inspira para seguir con ritual cautela los compases de la música tropical, de una cumbia colombiana, o de una guaracha y rumba caribeñas: "Dicen que las 
de Tepito tienen fuego en la cintura cuando las ven bailando una rumba" (Noche 77). En otras ocasiones, las letras del popular y romántico bolero ranchero, una ". . música con la que se canta a las alegrías y a las tristezas que nacen y mueren en lo más profundo de los corazones que aman" (Quinceañera 17), les incita abiertamente a beber y los acompaña desde el génesis de la parranda hasta su culminación, concluyendo a veces en un arrojo violento de realidades guardadas muy dentro del alma: "si hasta en mi propia cara/ coqueteabas mi vida/ que sera a mis espaldas/ y yo preso por ti" (Chin Chin 99). Ya bajo el aturdimiento del licor se la siguen en prostíbulos y cabarets, donde los aguardan más música y brazos femeninos; venta y compra de amor al mejor postor, comercio de carne humana común entre la clase proletaria del Distrito Federal, y que se lleva a cabo en Chin Chin, al estar embriagado el cuerpo y el alma ante la música del danzón:

Tomamos un taxi, nos llevo al imperio, nos lo recomendo el chofer de taxi ellos saben mucho acercas de donde esta el ambiente nocturno entramos el ambiente era asfixiante, prostitutas por todos lados una orquesta tocaba, por cierto muy mal, danzones el mesero nos señalo una mesa, pedimos una botella y nuestros respectivos seis refrescos. ... (131)

Celebran toda ocasión, aliviándose la cruda en la calle o cualquier cantina de esquina; en el proceso discuten de política y deportes, de la vida y sus experiencias. La invitación a la tomadera es febril y sin prejuicios e inhibiciones, hasta el teporocho invita al lector a "chupar" [beber alcohol], 
cantando y aullando una internacional canción de los Beatles (126-27) u otra pieza de arraigo popular en el Distrito Federal (Chin Chin 17), "de las que se sirve el autor para hacer resaltar la atmósfera popular ya creada" (Chiu-Olivares 99).

La fiesta se prolonga aritméticamente, pasando del anonimato de un día cualquiera hasta llegar al 15 de septiembre. ${ }^{12}$ En forma circular aparece la violencia, y la sangre corre desintegrando el yo y todo lo que le rodea; se pierde el respeto personal y la familia; los amigos mueren o casan; entonces, la soledad invade lo profundo del ser, y el dolor o tormento de la vida requiere de un remedio etílico inmediato, que enajene el ánimo. De esta manera se precipita un cambalache del todo por nada. Por consiguiente, la metamorfosis del alcohol conduce al protagonista y a otros hacia un infierno terrenal inescapable; a un circo de marionetas y payasos melancólicos, donde el bufón con más experiencia ríe y baila al ritmo de The Rolling Stones para entretener y consecuentar la apatía y el dolor personal y ajeno.

La cadencia del teporocho es un preámbulo a la historia de una vida y muchas sin pertenencia. Es el haber nacido y ser parte de un predeterminado estrato social, especie de casta ínfima que somete y convierte en perdedor irremediable y agónico a cada ser humano que habita debajo de la predominante piel mestiza de Tepito. Estas personas están convencidas y conscientes de pertenecer al submundo social de una

12 Aniversario de la guerra de independencia mexicana de la Corona de España. Se inició con un levantamiento armado en el actual pueblo de Dolores Hidalgo, Guanajuato, el 15 de septiembre de 1810. 
ciudad a punto de deshumanizarse por completo; una urbe grotesca, marcada por enormes diferencias sociales que arrastran y tratan de esconder a su lumpen en barrios proletarios, callejones "salsipuedes" (Chin Chin 16), cárceles y vecindades. Y por eso cuando los títeres tienen en la bolsa unos cuantos pesos, es una prioridad beber cuando el coraje ya no se aguanta; sumado a la frustración cotidiana, se les revuelve el estómago, y llegan al límite donde está a punto de reventar el hígado. El regocijo o la alegría inmensa de la vida ejercita su llamado ante la desgracia y tristeza personal o ajena, entonces continúan bebiendo, y comen o bailan con frenesí hasta las últimas consecuencias. Tratan de atragantarse de vida para tener las fuerzas y el cinismo necesario que les haga reír y llorar frente al fatalismo inequívoco de la pobreza que acosa y rodea la existencia tepiteña en la esfera de Ramírez.

Festejan con alegría, tristeza y vehemencia, al verse y saberse desprotegidos y abandonados por la misma sociedad civil que los parió. En las actitudes de la fiesta y el baile de barrio, renace y muere felizmente el olvido personal y colectivo, don necesario y substancia ritual imprescindible para poder vivir de verdad y no a medias, y así evitar una muerte mediocre en vida, ante la cruel irresponsabilidad y sordera de instituciones creadas y respaldadas por un sistema político-económico burgués, ineficiente y ajeno a los intereses del pueblo y de los miserables, a quienes de hecho se sigue abusando, convirtiéndoles en víctimas del desprecio y escarnio social. A esta gente aún se les relega, controla y margina socialmente con gigantescas cantidades de alcohol y un ridículo salario. En un absurdo círculo vicioso, nacen, crecen y mueren en la 
barriada, donde el saber tomar de verdad es requisito indispensable para sobrevivir en un ámbito sin mucha esperanza, y de esta forma poder escapar del ente, de la aterradora estrechez económica y la árdua responsabilidad que implica tener un trabajo de salario mínimo y pertenecer a una familia pobre. En Chin Chin, se parrandea hasta perder la vergüenza personal y a los seres queridos; el alcohol ofrece inmensas posibilidades de acción y libertad; de perderse en el infinito espacio de sus efluvios oníricos. Bajo los efectos del vino o la mariguana se puede llegar a un eudemonismo pleno, sin sociedad, ni clases sociales y gobierno, sin responsabilidades, miseria, corrupción o pudor. Éste ofrece simplemente la posibilidad pasajera de ser y estar.

En el Handbook of Latin American Literature (Foster), se establece una relación directa de las diversas causas y efectos del abuso del alcohol y drogas en Chin Chin el teporocho con el paupérrimo microcosmos de Tepito, cuya vida es documentada en un estilo (438) que describe formas de ser y sentir, carácteres y costumbres socio-culturales de sus habitantes, las cuales exterioriza por medio de las preferencias etílicas, culinarias y musicales. Armando Ramírez logra revelarnos todo un contexto social que involucra a una enorme diversidad de individuos que en conjunto sufren una espantosa segregación social desde el momento en que nacen: "Lugar hecho de residuos, lugar despreciado y nostalgizado, ..." (Tepito 15). En esta atmósfera, las posibilidades de escape de la "herencia y el medio ambiente" (Cortés E. 247) del alcoholismo son nulas.

John Brushwood nos dice que "Chin Chin el teporocho es una versión urbana de La vida inútil de Pito Pérez" ("A place to Belong" 341), 
y hasta cierto punto es verdad; pero, tocante al alcohol hay una diferencia muy importante: Pito Pérez se da cuenta que su decisión es emborracharse a morir: "No, yo seré malo hasta el fin, borracho hasta morir congestionado por el alcohol" (Romero R. 90). En Chin Chin, el alcoholismo parece ser algo predestinado por la clase social, y la idea del fatalismo se nota en los renglones de la canción que interpreta Javier Solís, "Borracho:"

\section{Borracho yo he nacido \\ borracho yo he crecido \\ $y$ se que sinceramente \\ borracho he de morir (Chin Chin 17)}

En la novela, se bebe hasta las últimas consecuencias; el gusto por la constante celebración culmina en vómitos de alcohol y comida, traición, desengaño, muerte, melancolía y finalmente en la miseria de la calle; una trayectoria que recuerda en detalle Chin Chin:

... mi primera borrachera, me duro cerca de quince dias, despues descanse tres y me volvia emborrachar ahora fueron tres meses, mi tio me llevo a alcoholicos anonimos, me estuve absteniendo cerca de un mes a pesar de las ganas inmensas que me daban, pero todo fue en vano, ahora llevo mas de año y medio tomando todos los dias, duermo en el callejon de "salsipuedes".... (153) 


\section{El contexto de las ideas}

En Chin Chin el teporocho emanan una compleja variedad de ideas en los diálogos y el monólogo, y en general germinan bajo un estado de ebriedad constante. La achispada omnisciencia del protagonista se sirve del fluido lenguaje tepiteño para expresar una realidad propia y ajena. El texto en sí, como ya hemos visto, con sus personajes alcohólicos expone abiertamente las condiciones y problemas sociales, económicos y políticos de toda una etapa histórica en el Distrito Federal, México 1968. La novela establece una conexión ideológica de carácter universal, con la aparición del movimiento estudiantil popular de 1968 (Fernández y Rodríguez 13: 7).

- dice mi hermana que estan en huelga que porque unos granaderos se metieron a una escuela de las que hay en la ciudadela y golpearon a los alumnos que estaban en sus salones de clases.

- pero porque se metio la policia a las escuelas?

En base a la crítica literaria, es necesario subrayar que el movimiento del 68 se percibe aquí, como un simple suceso (El Nacional 8 octubre 93: 13), además, la "proyección de la tragedia de Tlatelolco en la novela mexicana es complicadísima" (Brushwood, La novela 27); pero el resultado de ésta, es una de las causas que conducen a Rogelio a volverse teporocho.

Ante el advenimiento de los juegos olímpicos en la capital, los beodos personajes se desplazan diariamente entre teporochos, alcohólicos $\mathrm{y}$ otros borrachos, en un ambiente de mediocridad y falto de oportunidades. Siempre con un presente incierto y bajo el control de un 
gobierno malinchista, ${ }^{13}$ cuyas élites son responsables directas de haber enajenado y continuar enajenando al pueblo por medio del alcohol, para así asegurarse de establecer una segura y fructífera apertura a la inversión extranjera, con el pretexto de conducir a la ciudad y al país hacia el umbral de la supuesta modernidad del mundo desarrollado. Ramírez logra relatar una serie de sucesos de apariencia trivial y desordenada, en donde se encuentra sin engaño alguno, el entreguismo nacional e influencia del capital extranjero en México:

... fab, ajax, lux, mun, gerber, nabisco, kleenex, colgate, choco milk, oko, nestle, escuchar y atender las preguntas de las señoras: ¿en donde esta el shampoo alberto Vo 5, los lapices labiales, lapices para las cejas, para los parpados revlon, las medias y pantymedias cannon mills, o las cremas helencurtis-rubestein-maxfactor-pons-nivea-teatrical-etc. o el kotex, o las playtex con elastico en la cintura y las caderas y las pantorillas y esa terrorifica musica instrumental quedizquepararelajarlos nervios. ... (25-26)

Para reiterar lo expresado, el doctor Pablo González Casanova reflexiona e indica lo siguiente:

[L]as inversiones extranjeras no son un fenómeno puramente económico, sino un fenómeno social integral, cuyos orígenes y repercusiones abarcan toda la vida social de

13 Malinchista: Para Octavio Paz, un malinchista es la persona contagiada por ideas extranjerizantes. Son partidarios de que México se abra al exterior (77). 
la nación que invierte y de la nación en que se invierte, tendiendo a alterar en la forma más inmediata la totalidad de la estructura económica, social y cultural de los países subdesarrollados. (Fernández y Rodríguez 13: 13)

A un lado de la severa y acertada crítica a la ". . sociedad de consumo-civilizada-establecida-enajenada-y todavia-atavica" (Chin Chin 58), sobresalen en las pláticas de borrachera, situaciones y acontecimientos de carácter local, nacional e internacional que reflejan el abuso extremo hacia el pueblo por parte del gobierno mexicano, sus sindicatos, ejército, policías y corruptos servicios de inteligencia extranjeros:

comenzamos a tomar, primero una caguama, luego otra y otra....

- ¿tu crees que los estudiantes boicoten las olimpiadas?

- no creo, ellos también son deportistas y tambien son patriotas saben que desprestigiarian al pais, si hicieran eso. - oye pero tu crees que los estados unidos esten metiendo la mano en esto?

- pues quien sabe, con eso que se cree el quijote de la mancha. ... (101)

En una etapa trascendental en el desarrollo social de México, contemplamos la avaricia y oportunismo de ciertos sectores en el poder que promueven el envilecimiento de las masas por medio del deporte, la televisión, el alcohol, la mariguana y los "chochos (pastillas)" (Chin Chin 113). El monólogo y los diálogos de Chin Chin hacen referencia a las primeras manifestaciones políticas del año 1968 y la consecuente matanza 
de Tlatelolco, ${ }^{14}$ la guerra árabe-israelí, ${ }^{15}$ el conflicto de Vietnam, la guerra civil española de 1936, la Revolución de Mayo, ${ }^{16}$ las relaciones MéxicoEstados Unidos y la crisis de braceros, el marxismo en Santiago de Chile, y la tragedia del estadio nacional de fútbol en Perú, ${ }^{17}$ entre otros. Además,

14 La periodista Elena Poniatowska describe en La noche de Tlatelolco, el conflicto estudiantil que se gestó en el año 1968, el cual culmina con una brutal represión por parte del gobierno de Gustavo Díaz Ordaz, el 2 de octubre del mismo año. Se encarcela, tortura y asesina a sangre fría a un número indeterminado de estudiantes, mujeres, niños y ancianos. En Ahí viene la plaga, el escritor José Agustín menciona la participación de "cinco mil soldados y muchos agentes policiacos, la mayoría vestidos de civil. Tenían como contraseña un pañuelo blanco envuelto en la mano derecha. El fuego intenso duró veintinueve minutos. Luego los disparos decrecieron pero no se acabaron" (118).

15 "A pesar de la oposición de los árabes, el estado de Israel se formó en 1948. Atacados por seis naciones de la Liga Árabe, los judíos se defendieron con éxito hasta el armisticio de 1949. Egipto negó a Israel el paso libre de sus barcos por el Canal de Suez e hizo incursiones en su territorio; Israel respondió en 1956, con una acción militar, que fue sostenida por la intervención de tropas francobritánicas. De nuevo estalló el conflicto en 1967, y tras una fulgurante campaña, Israel ocupó algunas zonas vecinas y la parte vieja de Jerusalén" (Pequeño Larousse 1374-1376).

16 Carlos Fuentes opina que el movimiento estudiantil francés de 1968, conocido como la "revolución de mayo," fue uno de los momentos "excepcionales de la vida contemporánea de Francia. El mayo parisino de 1968 conmovió al mundo entero" (La Jornada, 7 junio 1997: n. pág.). La gran revolución proletaria en China. El objetivo era transformar el antiguo sistema educativo chino, sus principios y métodos de enseñanza. Mes de mayo de 1966 (Kwong XIX-XI).

17 “En los estadios de fútbol, la tragedia que más víctimas ha cobrado fue la de 1964, en la capital de Perú. Cuando el árbitro anuló un gol, en los minutos finales de un partido contra Argentina, llovieron naranjas, latas de cerveza y otros proyectiles desde las tribunas ardientes de furia. Los gases y los balazos de los policías provocaron, entonces, una estampida. La carga policial aplastó a la multitud contra las puertas de salida, que estaban cerradas. Hubo más de trescientos muertos. Esa noche, 
se comenta la violenta neurosis citadina, la incompatibilidad e incomunicación humana, así como la falta de fe en la Iglesia Católica. Los comentarios de problemas regionales y conflictos de orden internacional que atañen a la condición humana, conducen dialécticamente a los personajes más allá del barrio de Tepito e influyen en su comportamiento al intuir el proceso de la dinámica social y económica de un sistema que los maltrata, oprime y es manipulado por intereses ajenos. Recurren al alcohol una y otra vez, para escapar de la infernal angustia creada por un proceso político-social que golpea y asesina indiscriminadamente a su gente, con balas y licor, predestinándolos a subsistir en la miseria.

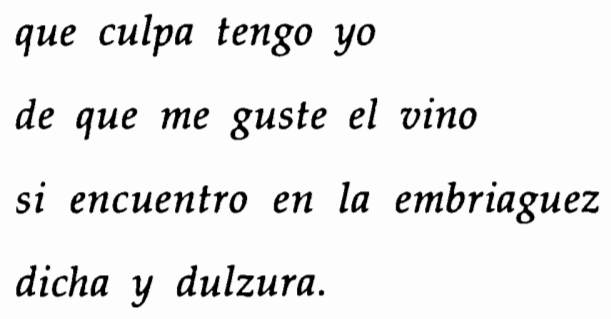

La voz y presencia del teporocho denuncia y comenta cada uno de los problemas más relevantes en la ciudad, la de ayer y la de hoy. Su acertado diálogo o soliloquio señala la pobreza y miseria producto de las diferencias sociales, de raza, y la falta de acceso a una educación adecuada a las necesidades populares; enuncia la escasez de casa-habitación y

un gentío protestó en las calles de Lima: la manifestación protestó contra el árbitro, no contra la policía" (Galeano 191). 
empleo digno; la drogadicción, prostitución y sobre todo el inherente impacto social del alcoholismo en Tepito. En Chin Chin el teporocho, se expone a los servicios públicos degradantes e ineficientes, tales como el transporte colectivo y la inseguridad pública en una urbe apática hacia su propia realidad social. Rogelio, aparte de estar consciente del entreguismo y la penetración cultural que les rodea, mantiene una filosofía religiosa muy realista:

no ustedes son casi misticos, no me refiero a todos los demas catolicos, a los de herencia y por costumbre, a los que nacieron en un hogar catolico y no tuvieron el chance de escoger sino la religion de sus padres y que por consiguiente la recibieron de herencia y ya despues acostumbrados a echarle a alguien la responsabilidad de sus actos se hicieron catolicos por costumbre. (89)

Dentro de toda la amargura y fatalismo que el autor nos presenta, encontramos una ideología predeterminada por el alcoholismo y la clase social. No hay escape, ni existe la posibilidad, razón o aliciente para dejar de tomar o escalar en busca del hipotético bienestar económico de la clase media. El asiduo vilipendio y corrupción de la llamada gente decente, también promueve un proceso social asombroso, obtuso y espeluznante, donde la carencia prevalece, ofreciendo un presente y futuro muy inciertos:

... ser teporocho es una enfermedad también, pero de la vida, es absolutamente contemplar la existencia desde la orilla del desencanto, del desencanto social, cultural y 
económico. Es aceptar los riesgos del alcohol y negar toda posibilidad social de poder existir: mugre, dormir donde agarre la noche, comer lo que queda en la basura, romper lazos familiares o amistosos y esperar qué ofrece la vida el día siguiente.... (Tepito 119)

Armando Ramírez ha declarado que al rescatar elementos de la cultura popular, ha evitado caer en lo folklórico o costumbrista. Revela que si un escritor de esta cultura antepone la denuncia a su trabajo, se le calificará como folklore, y a él como un autor que se lamenta de su desgracia. "Este, mi tejido verbal literario es como una adivinación del presente. No sé si realmente yo soy una copia de la realidad o la realidad me persigue" (El Nacional 10 noviembre 1994: 38). En conjunto, la maraña de ideas que aparecen en Chin Chin son consecuencia de una conciencia social que se desarrolla frente a la certidumbre de encontrarse inerme y vulnerable en un contorno social donde las condiciones de todo tipo y en su contexto ideológico general, no van a cambiar, y por el contrario, sus efectos sociales recrudecen con el alcohol y persiguen a los personajes a toda hora y en cualquier sitio, encaminándolos hacia una segura perdición del yo, en toda la extensión del pronombre, y con el poder destructor que acarrea el impacto social del alcoholismo. 


\section{Corolario}

Sin discusión alguna, Chin Chin el teporocho es una "novela fuerte" (Gutmann 189). El autor ha declarado que la "literatura es plasmar el mundo con sus defectos y con sus virtudes, con sus conflictos y contradicciones. .." (El Nacional 10 noviembre 1994: 38).

En entrevista, Arturo Melgoza indica que las hazañas etílicas, sus resacas y consecuente choque social en esta novela y en general, son un producto de esa industria tan próspera mundialmente con todas sus prensas hidráulicas, cilindros, calderas, barricas, empaques, vidrio para envases, metales y madera para alambiques, maquinaria y transporte, combustible y energéticos, fertilizantes y plaguicidas, grandes edificios e instalaciones, atractivos comercios que se emplean como instrumento para garantizar la manipulación colectiva y asegurar cómodamente el voraz enriquecimiento oligárquico. Tal enajenante impulso lo apoyan con venal actitud los medios de comunicación masiva con sus mensajes subyacentes. ¡Salud! No es que nos engañen. Lo que pasa es que nos gusta el drink a morir. Que continúen atesorando oro y poder las clases privilegiadas con tan refinado mecanismo. Junto con la drogadicción, la promiscuidad sexual, la ignorancia, la televisión y los deportes, controlan más eficazmente a una sociedad encanallada (Enero 31 de 1997).

Armando Ramírez expone el existente y estrecho vínculo del alcohol con una realidad mexicana cuyos estragos sociales e históricos proliferan más allá del perímetro de Tepito y de nuestra nación. John 
Brushwood aclara que "Ramírez no es autor ingenuo sino un escritor que conoce mucha literatura e historia" (La Novela 66).

La manifestación del alcoholismo ya en etapa muy avanzada, aparece inequívocamente desde el principio del relato:

... se nos acerco un Teporocho: de barba rala, de frente brillosa de mugre, de manos hinchadas y uñas crecidas con mugre en las comisuras, al caminar rengeaba de la pierna derecha, su ropa raida y pesada por la mugre que se ha. . ido acumulando atraves de los meses de intensas borracheras . . diarias y noches de vigilia producto de esa sed espantosa, .... $(15-16)$

Para así continuarse a través de la intrínseca problemática social que emana de la odisea etílica del protagonista y el resto de los residentes de la barriada, quienes en un agridulce y extraordinario proceso alcohólico, sobrellevan sus vidas entre vericuetos violentos, pobreza, marginación y desigualdad social; el rito de las pachangas y la explícita frustración personal.

La visión expuesta es la de un joven miembro de este estrato social y el código de comunicación es el lenguaje de Tepito, un lenguaje vulgar y anticonvencional. . . Pero el arte de Ramírez no se limita a la presentación de costumbres e ideologías de un grupo social, sino que ahonda en el sentimiento humano y en la complicada psicología de una sociedad. (Chiu-Olivares 95) 
Ramírez creció y se ha desarrollado en el medio social de Tepito. Su narrativa revela una preocupación constante, producto de las vivencias y experiencias propias, en tanto, su primera novela no es un producto muerto sino resultado de la conciencia de un autor conmovido. En Chin Chin el teporocho, la realidad es el punto de partida, retomando "elementos de la cultura popular: su lenguaje, anécdotas y personajes" con el propósito de dejar "implícito algún testimonio o alguna denuncia" (El Nacional, 10 noviembre 1994: 38).

En esta investigación se ha expuesto el impacto social del alcoholismo en Chin Chin el teporocho, exteriorizando así uno de los fenómenos sociales con más relevancia en el barrio de Tepito y en gran parte del mundo.

El ámbito de gestación y cada uno de los inherentes aspectos y efectos de esta "enfermedad crónica" (Castill 1), han sido expuestos y analizados en base a una diversidad de criterios internacionales que mantienen en conjunto un punto de vista objetivo y una posición neutral. Se garantiza de esta manera una perspectiva realista y aplicable a situaciones análogas en muchas regiones de la nación mexicana y otros países.

Pese a la muy limitada crítica literaria e información sobre la obra de Armando Ramírez, se ha recopilado información de distintas fuentes directas e indirectas, adecuándolas a las necesidades del proyecto, con la intención de contribuir modestamente a un posible entendimiento de una novela producto de uno de los más impresionantes fenómenos sociales de México, que en la actualidad comprende un número de ocho millones de alcohólicos detectados (La Jornada 21 enero 1997: n. pág.). 


\section{Bibliografía}

Agustín, José, José Buil, y Gerardo Pardo. Ahi viene la plaga. México: Joaquín Mortiz, 1988.

Alcántara Mercado, Estela. “La literatura es un ejercicio a largo plazo: para madurar se exige tiempo." Gaceta UNAM, edición internet. México, D.F., abril 1 de 1993.

Alegría, Fernando. Historia de la novela hispanoamericana. México: Ediciones de Andrea, 1966.

Anderson, Kenneth N., Lois E. Anderson, and Walter D. Glanze, eds. Mosby's Medical, Nursing, and Allied Health Dictionary. St. Louis, Missouri: Mosby, 1994.

Argyle, Michael. The Psychology of Social Class. London: Routledge, 1994.

Baguley, David. Emile Zola L'Assommoir. Cambridge: U P, 1992.

Benavente, Fray Toribio de. Relaciones de la Nueva España. Londres, 1848. México: UNAM, 1964.

Bartra, Roger. The Cage of Melancholy: Identity and Metamorphosis in the Mexican Character. Trans. Christopher J. Hall. New Brunswick, New Jersey: Rutgers U P, 1992.

Brain, Paul F., ed. Alcohol and Agression. London: Croom Helm, 1986.

Briggs, Donald C., and Marvin Alisky. Historical Dictionary of Mexico. Metuchen, N. J. : The Scarecrow Press, 1981.

Brushwood, John S. "A Place to Belong To: Armando Ramírez and Mexico City." Hispania 67: 3 (1984). 
---. La novela mexicana contemporánea (1967-1982). México: Grijalbo, 1985.

Cabrera, Luis. Diccionario de aztequismos. Ed. J. Ignacio Dávila Garibi. México: Oasis, 1974.

Calderón de la Barca, Frances. Life in Mexico. London, 1843. New York: Dutton, 1970.

Castill, Gustavo. "El alcohol, principal causa de muerte entre la población de 15 a 34 años." Gaceta UNAM, edición internet. México, D.F., abril 1 de 1993.

Clavijero, Francisco Javier. Historia antigua de México. Vol. 1. México, 1780. México: Porrúa, 1958.

Cockcroft, James D. Mexico: Class Formation, Capital Accumulation, and the State. New York: Monthly Review Press, 1983.

Cope, R. Douglas. The Limits of Ratial Domination: Plebeian Society in Colonial Mexico City, 1660-1720. Madison: U of Wisconsin P, 1994.

Cortés, Eladio., ed. Dictionary of Mexican Literature. Westport: Greenwood Press, 1992.

Cortés, Hernán. Cartas de Relación. Sevilla, 1522. México: Porrúa, 1988.

Cosío Villegas, Daniel, ed. Historia Moderna de México. Vol. 4: El Porfiriato, La vida social. Por Moisés González Navarro. México: Hermes, 1957.

Cue, Alberto. "La historia de la ciudad de México: una empresa paranoica." La Jornada, edición internet. México, D.F., octubre 20 de 1996. 
Cuevas, Mariano. Historia de la nación mexicana. Vol. 1. México: Buena Prensa, 1952.

Cumberland, Charles C. Mexico: The Struggle for Modernity. New York: Oxford U P, 1968.

Chiu-Olivares, M. Isela. La novela mexicana contemporánea (1960-1980). Madrid: Pliegos, 1990.

Dawson, Dawn P., Tracy C. Irons, L. Fleming Fallon, Jr., and Joyce I. Buchea, eds. Magill's Medical Guide: Health and Illness. Vol.1. Pasadena, California: Salem Press, 1995.

Eastman, Clive. Drink and Drinking Problems. London: Longman, 1984. Fernández Christlieb, Paulina, y Octavio Rodríguez Araujo. La clase obrera en la historia de México. En el sexenio de Tlatelolco (19641970). Coordinador Pablo González Casanova. Vol. 13. México: Siglo Veintiuno; México: Instituto de Investigaciones Sociales de la UNAM, 1985.

Fernández de Lizardi, Joaquín. El Periquillo Sarniento. México, 1896. México: Cicerón, 1953.

Figueroa, Fernando. "Festejaron las 300 funciones de la obra Noche de califas." El Nacional, edición internet. México, D.F., marzo 13 de 1993.

Florescano, Enrique. Memoria mexicana. Ensayo sobre la reconstrucción del pasado: época prehispánica-1821. México: Joaquín Mortiz, 1987. Foster, David William., ed. Handbook of Latin American Literature. New York: Garland, Publishing, 1992. 
Fuentes, Carlos. “¿Qué nos dice Francia? La Jornada, edición internet. México, D.F., junio 7 de 1997.

Galeano, Eduardo. El fútbol a sol y sombra. México: Siglo veintiuno, 1995.

García Robles, Jorge. "El consumo de drogas es cultura. Entrevista con Roger Bartra." La Jornada, edición internet. México, D.F., julio 21 de 1996.

Glantz, Margo. Esguince de cintura. Ensayos sobre narrativa mexicana del siglo XX. México: Consejo Nacional para la Cultura y las Artes, 1994.

González Peña, Carlos. Manual de gramática castellana. México: Patria, 1991.

Griffith, Edwards, et al. Alcohol Policy and the Public Good. Oxford: Oxford U P, 1994.

Gutmann, Mathew C. The Meanings of Macho: Being a Man in Mexico City. Berkeley: U of California P, 1996.

Harrison, Tinsley R. Harrison's Principles of Internal Medicine. New York: McGraw Hill, 1993.

Hernández, Francisco. Antigüedades de la Nueva España. México: Pedro Robredo, 1946.

Herrera Beltrán, Claudia. "Ocho millones de mexicanos son alcohólicos, informa el Conadic." La Jornada, edición internet. México, D.F., enero 21 de 1997.

Humboldt, Alexander de. Political Essay on the Kingdom of New Spain. 4 vols. London, 1811. New York: AMS Press, 1966. 
Jiménez, Armando. Tumbaburro de la picardía mexicana. México: Diana, 1977.

Kwong, Julia. Cultural Revolution in China's Schools, May 1966-April 1969. Stanford: Hoover Institution Press, 1988.

Leal, Luis. Historia del cuento hispanoamericano. México: Ediciones de Andrea, 1971.

Lewis, Oscar. Anthropological Essays. New York: Random House, 1970. Lope Blanch, Juan M. Atlas lingüistico de México. México: Colegio de México; México: F.C.E., 1990.

López de Gómara, Francisco. La Conquista de México. Zaragoza, 1552. Madrid: Historia 16, 1987.

MacDonald, Scott B. Dancing on a Volcano: The Latin American Drug Trade. New York: Praeger, 1988.

Melgoza, Arturo. “Decadencia actual del pulque ...se cerraron pulquerías y se abrieron los "toreos..." " Impacto 7 mayo 1980: 21.

--. . "De pulquerías y "toreos." Fueron propiedad de ricos y nobles." Impacto 30 abril 1980: 28-29.

--- . "El pulque es humilde ante el coñac, brandy y ginebra. Pero el vino está presente en toda la historia del hombre." Impacto 28 mayo 1980; 4 junio 1980: 24-25.

-- . "El pulque es leyenda y además figura importante en la historia." Impacto 23 abril 1980: 20-21.

--- . "Fray Bernardino de Sahagún." Impacto 21 mayo 1980: 30-31.

--- . "Las 7 caídas de los ebrios. Tezcatzóncatl, dios de la mexicana bebida." Impacto 14 mayo 1980: 21. 
--- . Entrevista telefónica. 31 de enero 1997.

Mendieta, Fray Gerónimo de. Historia eclesiástica indiana. Vol. 1.

México, 1860. México: Chávez Hayhoe, 1945.

Minogue, Valerie. Zola L' Assommoir. London: Grant \& Cutler, 1991.

Monsiváis, Carlos. "Ahí está el detalle. El cine y el habla popular." La

Jornada, edición internet. México, D.F., abril 17 de 1997.

--- Días de guardar. México: Era, 1970.

Newmark, Maxim. Dictionary of Spanish Literature. New York:

Philosophical Library, 1956.

Paz, Octavio. El peregrino en su patria: historia y política de México. Ed.

Octavio Paz y Luis Mario Schneider. México: Fondo de Cultura Económica, 1987.

Pequeño Larousse ilustrado. Por Ramón García-Pelayo y Gross. 14a ed. México: Larousse, 1990.

Piccato, Pablo. "El paso de Venus por el disco del Sol": Criminality and Alcoholism in the Late Porfiriato. Mexican Studies 11.2 (1995): 203-241.

Poniatowska, Elena. La noche de Tlatelolco. Testimonios de historia oral. México: Era, 1988.

Prieto, Guillermo. "Los ceros sociales: el lépero." La Ciudad de México. Antología de lecturas, siglos XVI-XX. Ed. SEP. México: Secretaría de Educación Pública, 1995. 87.

Quiñones, Sam. "Capitalist Crucible." Mexico Business 1 junio 1996: $40-47$.

Rama, Angel. La ciudad letrada. Hanover: Ediciones del Norte, 1984. 
Ramírez, Armando. Chin Chin el teporocho. México: Grijalbo, 1989.

--- . Noche de califas. México: Grijalbo, 1983.

--- . Tepito. México: Grijalbo, 1989.

--- Quinceañera. México: Grijalbo, 1987.

Ramos, Samuel. El perfil del hombre y la cultura en México. México: Espasa-Calpe, 1982.

Riding, Alan. Distant Neighbors: A Portrait of the Mexicans. New York: Knopf, 1985.

Riva Palacio, Vicente. México a través de los siglos. Primera época.

Historia antigua, por Alfredo Chavero. Vol. 1. México, 1884-1889. México: Cumbre, 1953.

Rodríguez, Eva. "La literatura del movimiento: distintos 2 de octubre."

El Nacional, edición internet. México, D.F., octubre 8 de 1993.

Romero Flores, José Rubén. La vida inútil de Pito Pérez. México: Porrúa, 1970.

Romero, Héctor. El México de Diego Rivera: Crónicas capitalinas. México: Panorama, 1992.

Romero, Héctor, y José N. Iturriaga. México a la carta: la gastronomía viajera. Vol. 4. México: Alacena coabasto de cultura, 1991.

Sahagún, Fray Bernardino de. Historia general de las cosas de Nueva España. Vol. 1. México: 1570. México: Porrúa, 1956.

Santamaría, Francisco J. Diccionario de mejicanismos. México: Porrúa, 1959. 